Amasya Ilahiyat Dergisi - Amasya Theology Journal

ISSN 2667-7326 | e-ISSN 2667-6710

Aralık / December 2020, 15: 321-361

\title{
Huzur Derslerine Katılan Kırım Uleması ve Muhammed Emin Efendi'nin Tefsir Metninin Neşri
}

\author{
Süleyman GÜR \\ Dr. Öğr. Üyesi, Trabzon Üniversitesi, İlahiyat Fakültesi, \\ Tefsir Anabilim Dalı \\ Assistant Professor, Trabzon University, Faculty of Theology, \\ Department of Tafsir \\ Trabzon, Turkey \\ suleymangur@trabzon.edu.tr \\ orcid.org/0000-0002-7515-136X
}

\section{Makale Bilgisi / Article Information}

Makale Türü / Article Types: Araştırma Makalesi / Research Article

Geliş Tarihi / Received: 12 Eylül / September 2020

Kabul Tarihi / Accepted: 28 Ekim / October 2020

Yayın Tarihi / Published: 30 Aralık / December 2020

Yayın Sezonu / Pub. Date Season: Aralık / December

Sayı / Issue: 15 Sayfa / Pages: 321-361

Atıf / Cite as: Gür, Süleyman. "Huzur Derslerine Katılan Kırım Uleması ve Muhammed Emin Efendi'nin Tefsir Metninin Neşri [Crimean Ulama Who Participated in the Huzur Lessons and Commentary Texts and Publications of Mohammed Emin Efendi]". Amasya İlahiyat DergisiAmasya Theology Journal 15 (December 2020): 321-361.

https://doi.org/10.18498/amailad.794125.

İntihal / Plagiarism: Bu makale, en az iki hakem tarafından incelendi ve intihal içermediği teyit edildi. / This article has been reviewed by at least two referees and scanned via a plagiarism software.

Copyright $\odot$ Published by Amasya Üniversitesi, İlahiyat Fakültesi / Amasya University, Faculty of Theology, Amasya, 05100 Turkey. All rights reserved. https://dergipark.org.tr/amailad. 
322 | S. GÜR / Huzur Derslerine Katılan Kırım Uleması ve Muhammed Emin Efendi'nin Tefsir Metninin Neşri

\section{Crimean Ulama Who Participated in the Huzur Lessons and Publications of Quranic Commentary Texts of Mohammed Emin Efendi}

\section{Abstract}

During the Ottoman period, the tafsir (interpretation) lessons held in the presence of the Sultan in every year during Ramadan were called as "lessons in presence." The lessons, which began in 1172/1759, continued until the end of the Ottoman Empire. The lessons in presence were attended by the Sultan, the shaykh al-islam, the mukarrir (teacher) who would present the lecture, the interlocutors in the position of negotiators and other persons who were in the status of listeners. The mukarrir and interlocutors were chosen by the shaykh al-islam and appointed by the Sultan himself. The verses to be interpreted in the course were notified to mukarrir and the interlocutors two months ago for giving them time to get prepared for the lesson. The duration of each lesson was about two hours, and at the end of the lesson, starting from the highranking interlocutor, questions were directed to the mukarrir, and discussions were also held afterwards. After mukarrir made an exegesis of the verse, he would answer the questions and objections posed to him. The lessons in presence were the highest and most prestigious scientific councils in which a scholar could participate. Participating in this assembly also required being one of the Istanbul dersiâms (certified teachers). In the historical process, scholars from Anatolian cities attended these courses, as well as scholars from different regions of the Ottoman geography such as Ahiska, Dagestan and Bosnia. Some of these scholars were also from Crimea.

It is known that the Ottoman ulema were influential in Crimea and the Crimean ulema in the Ottoman geography from the time when Crimea was annexed to the Ottoman Empire. As a matter of fact, the Crimean scholars served in highlevel positions such as professorship, mufti, judge, and cadilesker in important centers of the Ottoman Empire such as Istanbul, Mecca, Medina, Jerusalem, Baghdad, Damascus and Egypt. This situation also continued in the same way after the Russian invasion of Crimea. In this study, some names such as Abdülhalim Efendi (d. 1210/1795), Muhammed (Emin) Efendi (d. 1243/1827), Abdullah Efendi (d. 1242/1827), Abdülhayy Efendi (d. 1339/1920), Ahmed Efendi (d. 1205/1791), Ali Şücâî Efendi (d. 1341/1922), Hasan Rüşdü Efendi (d. 1311/1894), Selim Efendi (d. 1260/1844) and Şerafeddin Şerif Efendi (d. 1331/1913), who attended to the lessons in presence, will be discussed and in this context, a brief information will be given about their life stories, the years they attended lessons in presence, their positions in the assembly and their 
S. GÜR / Crimean Ulama Who Participated in the Huzur Lessons and Publications of Quranic Commentary Texts of Mohammed Emin Efendi| 323

scientific rank, and then, the work of the lesson in presence that Crimean Muhammed Emin Efendi gave will be analyzed and transcribed.

The only source regarding the content of the lessons in presence is the texts of teaching and negotiations. However, few of these texts survived to the present day, especially those with old dates. One of them belongs to Muhammed Efendi of Crimea. This 13-leaf work is kept at the Turkish Manuscripts in the Section of Istanbul University Library at number 7297 as a manuscript, and its language is Turkish. This work, in which the verses 139-142 of Surah Âl- Imrân discussed in the 3rd assembly of lessons in presence in the year 1238 and were interpreted during the reign of Sultan Mahmud III, gives some ideas about the content of the lessons in presence and the method of interpretation of the verses. Just like Baydâvî's Anvâru't-Tanzîl and Fahruddîn al-Râzî's Mefâtîh which are used as the main sources, in the work the method of interpretation of the narration is used, which only the text of the negotiation is included, but it is seen that the method of discernment is also emphasized. In this context, the verses are interpreted through verses, hadiths, and the views of early scholars, as well as extensive linguistic analyses, theological discussions, the effect of readings on meaning and similar issues were mainly discussed. As far as it is understood, this method, which is also frequently used in the tafsir (interpretation) texts of classical period, was also adopted and applied by the mukarrirs of lessons in presence.

According to our findings in this study, ten scholars from Crimea, two of whom were mukarrirs and eight of whom were interlocutors, attended the lessons in presence, which were a very high-level scientific activities. This data have been obtained from the available records. Information on the total number of people attending classes and the number of assemblies should be approached with caution, since no records of some years have survived. These numbers are likely to change as new documents become available.

Keywords: Tafsir, Ottoman, Crimea, Huzur Lessons, Muhammed Emin Efendi.

\section{Huzur Derslerine Katılan Kırım Uleması ve Muhammed Emin Efendi'nin Tefsir Metninin Neşri}

Öz

Osmanlı döneminde her yıl Ramazan ayında, padişahın huzurunda yapılan tefsir derslerine "huzur dersleri" denilmiştir. 1172/1759 yılında başlayan dersler, Osmanlı Devleti'nin sonuna kadar sürmüştür. Huzur derslerine, başta padişah olmak üzere, şeyhülislâm, dersi sunacak olan mukarrir, müzâkereci 
324 | S. GÜR / Huzur Derslerine Katılan Kırım Uleması ve Muhammed Emin Efendi'nin Tefsir Metninin Neşri

konumundaki muhataplar ve dinleyici statüsündeki diğer zâtlar katılırdı. Mukarrir ve muhataplar şeyhulislâm tarafından seçilir, padişah tarafından atanırdı. Derste tefsir edilecek âyetler iki ay önce mukarrir ve muhataplara bildirilir, derse hazırlanmaları sağlanırdı. Her dersin süresi iki saat civarında olup ders bitiminde yüksek rütbeli muhataptan başlamak üzere sırasıyla mukarrire sorular sorulur, müzâkereler yapılırdı. Mukarrir âyetin tefsirini yaptıktan sonra kendisine yöneltilen sorulara ve itirazlara cevaplar verirdi. Huzur dersleri, bir âlimin bulunabileceği en yüksek ve prestijli ilim meclisi idi. $\mathrm{Bu}$ meclise iştirak etmek de İstanbul dersiâmlarından olmayı gerektiriyordu. Söz konusu derslere Anadolu şehirlerinden âlimler katıldığı gibi Ahıska, Dağıstan, Bosna gibi Osmanlı coğrafyasının farklı bölgelerinden âlimler de katılmışlardır. Bu âlimlerin bir kısmı da Kırımlıdır.

Kırım Osmanlıya bağlandığı andan itibaren Osmanlı ulemasının Kırım'da, Kırım ulemasının da Osmanlı coğrafyasında etkili oldukları bilinmektedir. Nitekim Kırım uleması İstanbul, Mekke, Medine, Kudüs, Bağdad, Şam, Mısır gibi Osmanlı Devleti'ne bağlı olan devrin önemli merkezlerinde müderrislik, müftülük, kadılık, kadıaskerlik gibi üst düzey vazifelerde görev yapmışlardır. Bu durum, Rus işgalinden sonra da aynı şekilde devam etmiştir. Bu çalışmada Kırım ulemasından huzur derslerine katılan Abdülhalim Efendi (öl. 1210/1795), Muhammed (Emin) Efendi (öl. 1243/1827), Abdullah Efendi (öl. 1242/1827 sonras1), Abdülhayy Efendi (öl. 1339/1920), Ahmed Efendi (öl. 1205/1791 sonrası), Ali Şücâî Efendi (öl. 1341/1922), Hasan Rüşdü Efendi (öl. 1311/1894), Selim Efendi (öl. 1260/1844) ve Şerafeddin Şerif Efendi (öl. 1331/1913) ele alınacak ve bu bağlamda hayat hikâyeleri, huzur derslerine katıldıkları yıllar, bulundukları meclisteki konumları ile ilmî rütbeleri hakkında kısaca bilgi verilecek, ardından Kırımlı Muhammed Emin Efendi'nin takrir ettiği huzur dersine ait eser tahlil edilip transkripsiyonu yapılacaktır.

Huzur derslerinin muhtevasına dair yegâne kaynak, takrir ve müzâkere metinleridir. Ancak bu metinlerden günümüze ulaşanlar ve bilhassa eski tarihli olanlar oldukça azdır. Bunlardan biri de Kırımlı Muhammed Efendi'ye aittir. 13 varaklık bu eser, İstanbul Üniversitesi Kütüphanesi, Türkçe Yazmalar Bölümü nr. 7297 'de yazma halinde olup dili Türkçe'dir. Sultan II. Mahmud devrinde, 1238 senesinde icra edilen huzur derslerinin III. meclisinde müzâkere edilen Âli İmrân sûresinin 139-142. âyetlerinin tefsir edildiği bu eser huzur derslerinin muhtevasına ve âyetlerin tefsir metoduna dair bazı fikirler vermektedir. Sadece müzâkere metninin yer aldığı eserde, tıpkı temel kaynak olarak kullanılan Beydâvî'nin Envâru't-Tenzîl'i ile Fahruddîn er-Râzî'nin Mefâtîh'inde olduğu 
S. GÜR / Crimean Ulama Who Participated in the Huzur Lessons and Publications of Quranic Commentary Texts of Mohammed Emin Efendi| 325 gibi, rivayet tefsir yöntemi de kullanılmış olmakla birlikte dirâyet yöntemine ağırlık verildiği görülmektedir. Bu bağlamda âyetler âyetle, hadisle, ilk dönem âlimlerinin görüşleri ile tefsir edildiği gibi ekseriyetle geniş dilsel tahlillere, kelâmi tartışmalara, kıraatların manaya etkisine ve benzeri konulara girilmiştir. Anlaşıldığı kadarıyla klasik dönem tefsir metinlerinde de sıkça kullanılan bu yöntem huzur dersleri mukarrirleri tarafından da benimsenmiş ve uygulanmıştır.

$\mathrm{Bu}$ çalışmadaki tespitlerimize göre, oldukça üst düzey ilmi bir faaliyet olan huzur derslerine, iki mukarrir sekiz muhatap olmak üzere Kırımlı on âlim katılmıştır. Bu veriler şu ana kadarki kayıtlardan hareketle elde edilmiştir. Bazı yıllarla ilgili hiçbir kayıt günümüze ulaşmadığından derslere katılan toplam kişi sayısı ile meclis sayısı konusunda verilen bilgilere ihtiyatlı yaklaşılmalıdır. Yeni belgelere ulaşıldıkça bu rakamların değişme olasılığı vardır.

Anahtar Kelimeler: Tefsir, Osmanlı, Kırım, Huzur Dersleri, Muhammed Emin Efendi.

\section{Giriş}

Osmanlı padişahları kuruluştan itibaren âlimleri etrafında toplama, ilmî sohbet ve tartışmalara katılma gibi konulara önem vermişler, gerek kendileri, gerekse ileri gelen devlet adamları ulemadan özel dersler almışlardır. Fâtih Sultan Mehmed döneminden itibaren bu tür faaliyetler artış göstermiştir. ${ }^{1}$ Ayrıca padişahlar devrin önde gelen âlimlerine "mutad tefsir dersleri" diye anılan tefsir dersleri yaptırmışlardır. Bir de her yıl Ramazan ayında, Beydâvî'nin (öl. 685/1286) Envârü't-tenzîl ve esrârü't-te'vîl adlı tefsiri esas alınarak padişahın huzurunda yapılan tefsir dersleri vardır ki bunlar "huzur dersleri" diye anılmıştır. Söz konusu derslere huzur-1 hümâyûn dersleri de denilmiştir. ${ }^{2}$ Huzur dersleri ile ilgili ilk örnek uygulama Sultan III. Ahmed zamanında Nevşehirli Damad İbrâhim Paşa (1131-1143/1718-

1 Mehmet İpşirli, "Huzur Dersleri", Türkiye Diyanet Vakfı İslâm Ansiklopedisi (Ankara: TDV Yayınları, 1989), 18/441-444.

2 Tayyarzâde Atâ, Osmanlı Saray Tarihi/Tarih-i Enderun, nşr. Mehmet Arslan (İstanbul: Kitabevi, 2010), 1/314; Mehmet Zeki Pakalın, Osmanl Tarih Deyimleri ve Terimleri Sözlü̆̆̈̈̈ (İstanbul: Milli Eğitim Bakanlığı, 1993), “Huzur Dersleri”, 1/860. 
326 | S. GÜR / Huzur Derslerine Katılan Kırım Uleması ve Muhammed Emin Efendi'nin Tefsir Metninin Neşri

1730) tarafından 1136/1724 yılında yapılmıştır. ${ }^{3}$ Sonraki yıllarda bu dersler daha sistemli hale gelmiş ve hatta 1140 Ramazan'ında, III. Ahmed bu derslerin birini başından sonuna kadar takip etmiştir. Bu derslerin resmiyet kazanması ise 1172/1759 yılında Sultan III. Mustafa'nın irade ve fermaniyla olmuştur. ${ }^{4}$

$\mathrm{Bu}$ şekilde resmileşen Huzur dersleri, arada bazı kesintiler dışında Osmanlı Devleti'nin sonuna kadar sürmüştür. Son ders 1341 senesi Ramazan'ında (Mayıs 1923) yapılmış olup, 26 Receb 1342 (4 Mart 1924) tarihinde hilâfetin kaldırılması ile 165 yıl boyunca devam eden huzur dersleri tarihe karışmıştır. ${ }^{5}$

Huzur derslerine, başta padişah olmak üzere, şeyhülislâm, dersi sunacak olan mukarrir, müzâkereci konumundaki muhataplar ve dinleyici statüsündeki diğer zâtlar katılırdı. Bunlara ilaveten padişah bazı önemli misafirlerini derse dâhil edebiliyordu. Başta takdim heyeti olmak üzere padişah ve dinleyiciler de, yerde minderler üzerinde oturarak dersi takip ederdi. ${ }^{6}$

Mukarrir ve muhataplar şeyhulislâm tarafından seçilir, padişah tarafından onanırdı. Derste takrir edilecek âyetler yaklaşık iki ay önce mukarrir ve muhataplara bildirilir, derse hazırlanmaları sağlanırdı. Her dersin süresi iki saat civarında olup ders bitiminde yüksek rütbeli muhataptan başlamak üzere sirasıyla mukarrire sorular sorulur, müzâkereler yapılırdı. ${ }^{7}$ Mukarrir âyetin tefsirini yaptıktan sonra kendisine yöneltilen sorulara ve itirazlara cevaplar verir, böylece ilmî bir

3 Ömer Kara, “Osmanlı'da Huzur Dersleri Geleneği Literatürü”, Türkiye Araştırmaları Literatür Dergisi 9/18 (2011), 521.

4 Ebül'ulâ Mardin, Huzur Dersleri (İstanbul: İsmail Akgün Matbaası, 1951), 1/62; İsmail Hakkı Uzunçarşılı, Osmanlı Devletinin Ilmiye Teşkilatı (Ankara: Türk Tarih Kurumu Yayını, 1965), 216; İpşirli, “Huzur Dersleri”, 18/441-444; Kara, “Osmanlı'da Huzur Dersleri Geleneği Literatürü", 521.

5 Mardin, Huzur Dersleri, 1/62; İpşirli, “Huzur Dersleri”, 18/441-444; Kara, “Osmanlı' da Huzur Dersleri Geleneği Literatürü”, 522.

6 Halit Ziya Uşaklıgil, Saray ve Ötesi=Son Hatıralar (İstanbul: Özgür Yayınları, 2003), 431; Uzunçarşılı, Osmanlı Devletinin İlmiye Teşkilatı, 219; Aydın Temizer, "Osmanlıda Huzur Dersi Örnekleri Tahlil ve Tenkitli Tefsir Metni Neşirleri I", Sakarya Üniversitesi Ilahiyat Fakültesi Dergisi 15/28 (2013), 66.

7 Pakalın, Osmanlı Tarih Deyimleri ve Terimleri Sözlüğ̈̈, "Huzur Dersleri”, 1/862. 
S. GÜR / Crimean Ulama Who Participated in the Huzur Lessons and Publications of Quranic Commentary Texts of Mohammed Emin Efendi| 327 mübâhase cereyan ederdi. Bu yüzden âyetlerin tefsiri son derece yavaş ilerlerdi. ${ }^{8}$

Huzur dersine katılan muhatapların sayısında zaman içerisinde farklılıklar olmuştur. Dersler, başlangıçta 1 mukarrir 5 muhatap toplam 6 kişi tarafından takdim edilirken, 1189 yılı itibari ile bu sayı önce 8'e yükselmiş sonra sırasıyla 12, 13 ve 14'e kadar ulaşmıştır. 1293 yılında 15'e, 1316 yılında ise 16'ya kadar çıkmıştır. Bu tarihten sonra katılımcı sayısında herhangi bir değişiklik olmamıştır. ${ }^{9}$

Huzur derslerinin icra edildiği meclislerin sayısında da değişiklikler olmuştur. Özellikle ilk dönemlerde Ramazan aylarında 8, 9, 10, 11, 12, 13, 15, 18 gibi farklı sayıda oturumlarla yapilan huzur derslerinde meclis sayısı 1180/1766 yılında 19'a kadar ulaşmıştır. ${ }^{10}$ 1189/1775 senesinde alınan bir kararla meclis sayısı 8 ile sınırlandırılmıştır. Bu tarihten itibaren 1200/1785 senesine kadar huzur dersleri mutad olarak her Ramazan'da 8 ayrı oturum şeklinde icra edilirken 1200/1785 yılından itibaren bu meclislere bir de "mukarrirler meclisi" ilave edilmiştir. Yilda bir kez toplanan bu meclisin muhataplarını mukarrir ve muhatap niteliğindeki zâtlar oluştururdu. Hatta bazen bu oturumlara dışarıdan müderrisler de katılırdı. Bunlara ilaveten, "sudur meclisleri" diye tabir edilen bir oturum daha vardir ki bu oturuma ilmî yönden yüksek rütbelere sahip olup mutad meclislere katılma salahiyetini kaybedenler iştirak ederlerdi. ${ }^{11}$

XIX. yüzyıldan itibaren huzur dersleri için yeni bazı ilkeler belirlenmiş ve bir teamül oluşturulmuştur. Buna göre mukarrir ve muhatapların İstanbul ruûsunu almış, resmi bir görevi olmayan ve İstanbul'da oturan âlimler arasından seçilmesi esası getirilmiştir. Ayrıca herhangi bir meclisin mukarrirliği boşalınca bir sonraki meclisin mukarririnin oraya tayin edilmesi, son meclisin mukarrirliği

8 İpşirli, “Huzur Dersleri”, 18/441-444.

9 Mardin, Huzur Dersleri, 1/84 vd.; İpşirli, "Huzur Dersleri", 18/441-444; Kara, “Osmanlı' da Huzur Dersleri Geleneği Literatürü", 526.

10 Mardin, Huzur Dersleri, 1/69; Temizer, "Osmanlıda Huzur Dersi Örnekleri”, 68.

11 Mardin, Huzur Dersleri, 1/84-88; Ömer Kara, "İslâm Geleneğinde Ümerâ Huzurundaki Bilimsel Toplantıların Osmanlıcası: Huzur Dersleri", Osmanlı Toplumunda Kur'an Kültürü ve Tefsir Çalışmaları 2 (İstanbul: İlim Yayma Vakfı Kur'ân ve Tefsir Akademisi, 2013), 335-336. 
328 | S. GÜR / Huzur Derslerine Katılan Kırım Uleması ve Muhammed Emin Efendi'nin Tefsir Metninin Neşri

boşaldığında ise oraya ilk meclisin baş muhatabının getirilmesi teamül haline gelmiştir. ${ }^{12}$

Huzur derslerinde öncelik sırası, ruûstaki kıdeme göre belirlenmekteydi. ${ }^{13} \mathrm{Bu}$ yüzden derslere katılan ulemanın rütbeleri önem arz etmekteydi. Bu rütbeler aşağıdan yukarıya doğru şu şekilde sıralanmaktadır: İbtidâ-i Hâric, Hareket-i Hâric, İbtidâ-i Dâhil, Hareket-i Dâhil, Mûsılâ-i Sahn, Sahn-1 Semân, İbtidâ-i Altmışlı, Hareket-i Altmışlı, Mûsılâ-i Süleymâniye, Süleymâniye, Hâmise-i Süleymâniye, Dâru'lHadis-i Süleymâniye. ${ }^{14} \mathrm{Bu}$ mertebelerin en yükseğini, Dâru'l-Hadis müderrisleri oluşturmaktayd $1 .{ }^{15}$

Kaynaklardan anlaşıldığına göre huzur derslerinde Kadı Beydâvî'nin Envârü't-tenzîl ve esrârü't-te'vîl adlı tefsiri merkeze alınarak 1172 yılından itibaren padişah tarafından seçilen âyetler tefsir edilmiştir. 1180 senesinde sûre seçimine geçilmiş, 1200 yılından itibaren mushaf tertibiyle derslere devam edilmiştir. Bu şekilde Nahl sûresinin 26. âyetine kadar Kur'ân'ı Kerîm'in tefsiri yapılmıştır. Bu tertibin dışında ayrıca İsra, Fetih ve Saf sûreleri de huzur derslerinde tefsir edilmiştir. ${ }^{16}$

Ders takrir ve müzâkerelerinin kaydına gelince, ilk yıllarda kayıt tutulduğuna dair bir veriye şimdilik ulaşılamamıştır. Ancak 1177 yılında ${ }^{17}$ ve 1238 'de II. Mahmud'un saltanatı döneminde bazı kayıtların tutulduğu tespit edilmiştir. ${ }^{18} \mathrm{Bu}$ kayıt tutma işlemi resmi bir görevli tarafından değil, mukarrir ve muhatapların kişisel gayretleriyle ve dağınık bir şekilde yapılmıştır. Son dönemlerde ise Tikveşli Yusuf Ziyaeddin Efendi, Gümülcineli Ahmed Asım Efendi gibi bazı mukarrirlerin ve Eğinli Muhammed Hulusi Efendi gibi muhatapların yine gönüllülük esasına göre ancak daha düzenli kayıtlar tuttuğu

12 Mardin, Huzur Dersleri, 1/92-93, 104; İpşirli, “Huzur Dersleri”, 18/441-444; Temizer, “Osmanlıda Huzur Dersi Örnekleri”, 67.

13 Pakalın, Osmanlı Tarih Deyimleri ve Terimleri Sözlüğü, “Huzur Dersleri”, 1/862.

14 Pakalın, Osmanlı Tarih Deyimleri ve Terimleri Sözlüğü, "Altmışlı", 1/54; Enver Demirpolat, “Huzur Derslerine Katılan Harputlu Âlimler”, Firat Üniversitesi İlahiyat Fakültesi Dergisi 17/2 (2012), 214.

15 Pakalın, Osmanlı Tarih Deyimleri ve Terimleri Sözlüğü, “Hareket-i Altmışlı”, 1/740.

16 Kara, “Osmanlı'da Huzur Dersleri Geleneği Literatürü", 529.

17 Recep Arpa, "Huzur Derslerinde Kâdî Beydâvî Tefsiri mi Takip Edilirdi?”, Osmanlıda Tefsir Dersi Gelenekleri, ed. Ömer Kara vd. (İstanbul: İlim Yayma Vakfı Kur'ân ve Tefsir Akademisi Araştırmaları, 2018), 104.

18 Mardin, Huzur Dersleri, 2-3/1106. 
S. GÜR / Crimean Ulama Who Participated in the Huzur Lessons and Publications of Quranic

Commentary Texts of Mohammed Emin Efendi| 329

anlaşılmaktadır. Bunların bir kısmı yazma olarak günümüze ulaşmış, bir kısmı kendi notlarını kitaplaştırmış, ${ }^{19}$ bir kısmı ise zayi olmuştur. Yazma olarak elimize ulaşan az sayıdaki takrir ve müzâkere metinlerinden biri de Kırımlı Muhammed Efendi'ye aittir. Bu metin günümüze intikal edenlerin en eskilerinden olması yönüyle de ayrı bir öneme sahiptir. ${ }^{20}$

Osmanlı Devleti'nin kuruluş döneminde âlimler ilimlerini inkişâf ettirmek için Şam, Bağdat gibi ilim merkezlerine seyahat ederlerdi. Yükseliş döneminden sonra ise İstanbul bütün İslâm dünyasının en önemli ilim merkezi haline geldi. Padişahların da ilme ve ulemaya değer vermesi, İslâm coğrafyasının her bölgesinden âlimlerin İstanbul'a yerleşmesini sağladi. Bu âlimler kendileri ile birlikte memleketlerinin ilmî müktesabâtını da İstanbul'a taşıdılar. Huzur dersleri, bir âlimin bulunabileceği en yüksek ve prestijli ilim meclisi idi. Bu meclise iştirak etmek de İstanbul dersiâmlarından olmayı gerektiriyordu. Dolayısı ile âlimler bu payeyi elde etmek için bir rekabetin içerisine de girebiliyorlard1. ${ }^{21}$

Huzur derslerine tarihi süreç içerisinde Trabzon, Erzurum, Harput gibi Anadolu şehirlerinden İstanbul ruûsunu almış âlimler katıldığı gibi Ahıska, Dağıstan, Gümülcine, İşkodra, Bosna gibi Osmanlı coğrafyasının farklı bölgelerine mensup âlimler de katılmışlardır. Bu âlimlerin bir kısmı da Kırımlıdır. Kırım, Altın Ordu Devleti'nin bir vilayeti iken, 1441'de I. Hacı Giray yönetiminde hanlığa dönüştürüldü. 1475 senesinde I. Mengli Giray'ın, Fatih Sultan Mehmed'e müracaat etmesi üzerine Osmanlı Devleti'ne bağlandı. Ruslar tarafından 1783 yılında işgal edilinceye kadar 307 yıl boyunca Osmanlı hâkimiyetinde

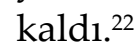

Kırım Osmanlı'ya bağlandığı andan itibaren Osmanlı ulemasının Kırım'da, Kırım ulemasının da Osmanlı coğrafyasında etkili oldukları bilinmektedir. Kırım ulemasının önemli bir bölümünün ilk

19 Bk. Pakalın, Osmanlı Tarih Deyimleri ve Terimleri Sözlüğ̈̈, “Huzur Dersleri”, 1/865.

20 Mardin, Huzur Dersleri, 2-3/1106. Ayrıntılı bilgi için bk. Kara, "İslâm Geleneğinde Ümerâ Huzurundaki Bilimsel Toplantıların Osmanlıcası: Huzur Dersleri”, 344-48; Kara, "Osmanlı' da Huzur Dersleri Geleneği Literatürü", 531.

21 Alparslan Kartal, "Huzur Derslerine Katılan Karslı Âlimler”, Kafkas Üniversitesi İlahiyat Fakültesi Dergisi 4/8 (2017), 231.

22 Halil İnalcık, "Kırım”, Türkiye Diyanet Vakfı İslâm Ansiklopedisi (Ankara: TDV Yayınlar1, 2002), 25/450-458. 
330 | S. GÜR / Huzur Derslerine Katılan Kırım Uleması ve Muhammed Emin Efendi'nin Tefsir Metninin Neşri

tahsillerinden sonra yüksek tahsil için başta İstanbul olmak üzere Anadolu'nun çeşitli merkezlerine geldikleri ve ilmiye sınıfında yüksek bir mevkide bulundukları bilinmektedir. Nitekim İstanbul, Mekke, Medine, Kudüs, Bağdad, Şam, Mısır gibi Osmanlı Devleti'ne bağlı olan devrin önemli merkezlerinde müderrislik, müftülük, kadılık, kadıaskerlik gibi üst düzey vazifelerde görev yapmış olmaları da bunu desteklemektedir. Bu durum, Rus işgalinden sonra, boyutu şartlara göre zaman zaman değişiklik arz etse de aynı şekilde devam etmiştir. ${ }^{23}$

Kaynaklarda, Molla Seyyid Ahmed b. Abdullah el-Kırımî (öl. 879/1474), Mahmud b. Süleyman (öl. 990/1582), İbrahim b. Abdullah (öl. 1001/1593), Hüseyin Efendi (öl. 1010/1602), Seyyid/Şerif Mûsâ Kelîmî (öl. 1054/1644), Mehmed Feyzi (öl. 1055/1645), Ebu'l-Bekâ Eyyûb b. Mûsâ (öl. 1095/1684), Mehmed b. Abdülhamid (öl. 1168/1755), Hamid b. Ahmed (öl. 1185/1771), İsmail Ferruh Efendi (öl. 1256/1840) gibi Kırımlı çok sayıda meşhur âlimden bahsedilmektedir. ${ }^{24} \mathrm{Bu}$ çalışmada, onların, sadece huzur derslerine katılanları ele alınacak ve bu bağlamda hayat hikâyeleri, huzur derslerine katıldıkları yıllar, bulundukları meclisteki konumları ile ilmî rütbeleri hakkında kısaca bilgi verilecek, ardından Kırımlı Muhammed Emin Efendi'nin takrir ettiği huzur dersine ait eser tahlil edilip transkripsiyonu yapılacaktır.

Huzur dersleri ile ilgili, Osmanl Tarih Deyimleri ve Terimleri Sözlüğ̈̈ (Mehmet Zeki Pakalın), Osmanlı Devletinin İlmiye Teşkilatı (İsmail Hakkı Uzunçarşılı) gibi çeşitli kaynak kitaplarda bazı bilgiler mevcuttur. Ancak bu konudaki en sistematik ve kapsamlı çalışma, konu ile ilgilenen bütün araştırmacıların vazgeçilmez müracaat kaynağı olan Ebül'ulâ Mardin'in Huzur Dersleri adlı üç ciltlik eseridir. Bu araştırmada da söz konusu eser temel kaynak olarak seçilmiştir. Bunların dışında huzur dersleri ile ilgili başka kaynaklar ve çeşitli ilmî çalışmalar da vardır. ${ }^{25} \mathrm{Biz}$ de bu çalışmalardan da istifade ederek hem Kırım uleması hakkında bilgi vermek hem de padişahın huzurunda icra edilen bir tefsir dersinde

23 Ahmet Yüksel - Zafer Karademir, “Ulema, Göç ve Devlet: Kırım Harbinden Sonra Osmanlı Ülkesine Göç Eden Ulemanın İskânına Dair Bazı Bilgiler", Ankara Üniversitesi Dil ve Tarih-Coğrafya Fakültesi Dergisi 52/1 (2012), 184.

24 Bursalı Mehmet Tahir, İdare-i Osmaniye Zamanında Yetişen Kırım Müellifleri (İstanbul: Matbaa-i Orhaniye, 1335), 1-38.

25 Bu çalışmalar için bk. Kara, "Osmanlı'da Huzur Dersleri Geleneği Literatürü", 519539. 
S. GÜR / Crimean Ulama Who Participated in the Huzur Lessons and Publications of Quranic Commentary Texts of Mohammed Emin Efendi| 331 ilk dönemlerde ne gibi konuların konuşulduğunu okuyuculara ulaştırmak istedik. Mukarrir ve muhatapları alfabetik sıraya göre ele aldik.

\section{Mukarrir Olarak Huzur Derslerine Katılan Kırımlı Âlimler Abdülhalim Efendi (öl. 1210/1795)}

Kırımlı dersiamlardan olan Abdülhalim Efendi, Vassafzâde Esad Efendi meşihatinde kassâm-1 askerî ve ders vekili, sonra Enderûn-i Hümâyun'a baş hoca, 1199/1787 yılında da Haremeyn müfettişi oldu. Daha sonraları fetva eminliği görevi yaptı. 1208 yılında Edirne kadısı, 1210/1795 yılında Mekke mollası oldu ve orada vefat etti. ${ }^{26}$

1198-1202 yılları arasında mukarrirlik yapmıştır. ${ }^{27} \mathrm{Bu}$ tarihlerin öncesi ve sonrasındaki yıllarla ilgili kayıtlar oldukça sınırlı olduğundan bu derslere hangi sıfatlarla toplam kaç kez katıldığı gibi konularda net bilgiler vermek şimdilik mümkün olamamaktadır. Ancak derslere katıldığı yıllarla ilgili bazı detaylar kayıtlarda vardır. Bu kayıtlardan anlaşıldığına göre; 1198 Ramazan'ında IV. meclisin mukarrirliğini asaleten, II. meclisin mukarrirliğini vekâleten yapmıştır. 10 Ramazan 1199 Pazar günü Yalı'da IV. meclisin mukarrirliğini, 8 Ramazan 1200 Pazartesi günü de yine aynı yerde ve aynı meclisin mukarrirliğini yapmıştır. Bu derste Fatiha tefsirine devam edilmiştir. 5 Ramazan 1201 Perşembe günü Mabeyn-i Hümâyûn'daki ictimada bu kez III. meclisin mukarrirliğini yapmıştır. 1 Ramazan 1202 Perşembe günü ise Has Oda'da Kütüphane hocası sıfatı ile I. meclisin mukarrirliğini yapmıştır. Bu meclisteki ders Bakara sûresinden takrir edilmiştir. ${ }^{28}$

Huzur Dersleri Katılım Tablosu. ${ }^{29}$

\begin{tabular}{|l|l|l|l|l|}
\hline Y1l (h/m) & Meclis & Görevi & Rütbesi & Mukarrir \\
\hline $1198 / 1784$ & IV. & Mukarrir & & Abdülhalim Efendi \\
\hline $1199 / 1785$ & IV. & Mukarrir & & Abdülhalim Efendi \\
\hline $1200 / 1786$ & IV. & Mukarrir & & Abdülhalim Efendi \\
\hline $1201 / 1787$ & III. & Mukarrir & & Abdülhalim Efendi \\
\hline $1202 / 1788$ & I. & Mukarrir & $\begin{array}{l}\text { Kütüphane } \\
\text { hocası }\end{array}$ & Abdülhalim Efendi \\
\hline
\end{tabular}

26 Mehmed Süreyyâ, Sicill-i Osmânî Yahud Tezkire-i Meşâhir-i Osmaniyye (I-IV/ıı), haz. Ali Aktan vd. (İstanbul: Sebil Yayınıevi, 1995), 3/343.

27 Mardin, Huzur Dersleri, 2-3/4 vd., 849.

28 Mardin, Huzur Dersleri, 2-3/4-7.

29 Mardin, Huzur Dersleri, 2-3/4 vd. 
332 | S. GÜR / Huzur Derslerine Katılan Kırım Uleması ve Muhammed Emin Efendi'nin Tefsir Metninin Neşri

\section{Muhammed (Emin) Efendi (öl. 1243/1827)}

Osmanlı döneminde müderrislik, mollalık ve mukarrirlik görevlerinde bulunmuş Kırımlı bir âlimdir. Kaynaklarda yer alan bilgilere göre 1225 yılında Kudüs mollası, 1232 yılı Recep ayında Mısır mollası, bilâhare Mekke mollası payesine nail olmuştur..$^{30} 13$ Rebiülahir 1236 'da Galata müderrisliğine tayin edilmiştir. 1236-1243 yılları arasında huzur hersleri mukarrirliği yapmıştır. 21 Rebiulevvel 1243 tarihinde vefat etmiştir. ${ }^{31}$

Mardin, 1236 senesinde mukarrirliğe tayin edildiğini ve 21 Rebiulevvel 1243 'te vefat ettiğini ifade etmekle birlikte muhataplik yaptığına dair kayıt düşmemektedir. ${ }^{32}$ Ancak huzur derslerine katılanları yıllara göre ele aldığı bölümdeki bilgilerden anlaşıldığına göre 1224-1228 yılları arasında huzur derslerine muhatap olarak katılmıştır. 1229-1234 yılları arası bu derslere katılanlar tespit edilemediğinden bu tarihlerle ilgili bilgi yoktur. 1235 yılı ile ilgili kayıtlarda ise II. meclisin ikinci muhatabı olduğu görülmektedir. Bu durumda 1236 'da muhataplıktan mukarrirliğe terfi ettiği anlaşılmaktadır. ${ }^{33} \mathrm{Bu}$ bilgilerden hareketle biz muhatap ve mukarrir olarak katıldığı meclisleri tabloda şu şekilde düzenledik.

Huzur Dersleri Katılım Tablosu. ${ }^{34}$

\begin{tabular}{|l|l|l|l|l|}
\hline Y1l (h/m) & Meclis & Görevi & Rütbesi & Mukarrir \\
\hline $1224 / 1809$ & VI. & 1.Muhatap & Mûsılâ-i Sahn & $\begin{array}{l}\text { Kilisli Mehmed } \\
\text { Kudsi Efendi }\end{array}$ \\
\hline $1225 / 1810$ & V. & 5.Muhatap & Mûsılâ-i Sahn & $\begin{array}{l}\text { Kilisli Mehmed } \\
\text { Kudsi Efendi }\end{array}$ \\
\hline $1226 / 1811$ & V. & 3.Muhatap & Mûsılâ-i Sahn & $\begin{array}{l}\text { Çarşambalı } \\
\text { Mehmed Said } \\
\text { Efendi }\end{array}$ \\
\hline $1227 / 1812$ & IV. & 10.Muhatap & Mûsılâ-i Sahn & $\begin{array}{l}\text { Tirnovalı } \\
\text { Müftizâde } \\
\text { Abdurrahim Efendi }\end{array}$ \\
\hline
\end{tabular}

30 Süreyyâ, Sicill-i Osmân̂̂, 4-1/338-339.

31 Mardin, Huzur Dersleri, 1/160.

32 Mardin, Huzur Dersleri, 1/111.

33 Mardin, Huzur Dersleri, 1/169 vd.

34 Mardin, Huzur Dersleri, 1/169 vd. 
S. GÜR / Crimean Ulama Who Participated in the Huzur Lessons and Publications of Quranic

Commentary Texts of Mohammed Emin Efendi| 333

\begin{tabular}{|l|l|l|l|l|}
\hline $1228 / 1813$ & IV. & 5.Muhatap & Mûsılâ-i Sahn & $\begin{array}{l}\text { Çarşambalı Said } \\
\text { Efendi }\end{array}$ \\
\hline $1235 / 1820$ & II. & 2. Muhatap & $\begin{array}{l}\text { Hareket-i } \\
\text { Altmışlı }\end{array}$ & $\begin{array}{l}\text { Kütahyalı Mehmed } \\
\text { Efendi }\end{array}$ \\
\hline $1236 / 1821$ & VI. & Mukarrir & $\begin{array}{l}\text { Hareket-i } \\
\text { Altmışlı }\end{array}$ & $\begin{array}{l}\text { Kırımlı } \\
\text { Muhammed Efendi }\end{array}$ \\
\hline $1237 / 1822$ & IV. & Mukarrir & $\begin{array}{l}\text { Mûsılâ-i } \\
\text { Süleymâniye }\end{array}$ & $\begin{array}{l}\text { Kırımlı } \\
\text { Muhammed Efendi }\end{array}$ \\
\hline $1238 / 1823$ & III. & Mukarrir & $\begin{array}{l}\text { Mûsılâ-i } \\
\text { Süleymâniye }\end{array}$ & $\begin{array}{l}\text { Kırımlı } \\
\text { Muhammed Efendi }\end{array}$ \\
\hline $1239 / 1824$ & II. & Mukarrir & $\begin{array}{l}\text { Mûsılâ-i } \\
\text { Süleymâniye }\end{array}$ & $\begin{array}{l}\text { Kırımlı } \\
\text { Muhammed Efendi }\end{array}$ \\
\hline $1240 / 1825$ & II. & Mukarrir & $\begin{array}{l}\text { Mûsılâ-i } \\
\text { Süleymâniye }\end{array}$ & $\begin{array}{l}\text { Kırımlı } \\
\text { Muhammed Efendi }\end{array}$ \\
\hline $1241 / 1826$ & II. & Mukarrir & $\begin{array}{l}\text { Mûsılâ-i } \\
\text { Süleymâniye }\end{array}$ & $\begin{array}{l}\text { Kırımlı } \\
\text { Muhammed Efendi }\end{array}$ \\
\hline $1242 / 1827$ & II. & Mukarrir & Süleymâniye & $\begin{array}{l}\text { Kırımlı } \\
\text { Muhammed Efendi }\end{array}$ \\
\hline
\end{tabular}

\section{Muhatap Olarak Huzur Derslerine Katılan Kırımlı Âlimler} Abdullah Efendi (öl. 1242/1827 sonrasi)

Abdullah Efendi'nin, 1224-1228 yılları arasındaki huzur derslerini Mûsıla-i Sahn rütbesi ile muhatap olarak takip ettiği kayıtlara geçmiştir. 1235-1240 tarihleri arasındaki derslere de Mûsıla-i Süleymâniye rütbesi ile katılmıştır. 1241'de Hâmise, 1242'de ise Dâru'l-Hadis rütbesi ile derslere devam etmiştir. ${ }^{35}$ 1229-1234 seneleri arasında yapılan huzur derslerine katılanların isimleri henüz tespit edilememiştir. ${ }^{36}$ Abdullah Efendi 1234 yılından sonraki derslere muntazaman katıldığına göre 1229-1234 yılları arasındaki derslere de muhatap olarak katılmış olmalıdır. Ayrica son yedi derse I. mecliste muhatap olarak katılması ve bunun da ötesinde son katıldığ Dârülhadis rütbesi ile baş muhatap olarak takip etmesi onun ilmî kariyerini ve ulema nezdindeki yerini göstermesi bakımından önemlidir.

35 Mardin, Huzur Dersleri, 1/171 vd.

36 Mardin, Huzur Dersleri, 1/194. 
334 | S. GÜR / Huzur Derslerine Katılan Kırım Uleması ve Muhammed Emin Efendi'nin Tefsir Metninin Neşri

Huzur Dersleri Katılım Tablosu. ${ }^{37}$

\begin{tabular}{|c|c|c|c|c|}
\hline $\mathrm{Y}_{11}(\mathrm{~h} / \mathrm{m})$ & Meclis & Görevi & Rütbesi & Mukarrir \\
\hline $1224 / 1809$ & V. & 10.Muhatap & $\begin{array}{l}\text { Mûsılâ-i } \\
\text { Sahn }\end{array}$ & $\begin{array}{l}\text { Divrikli Musannif } \\
\text { Osman Efendi }\end{array}$ \\
\hline $1225 / 1810$ & V. & 2.Muhatap & $\begin{array}{l}\text { Mûsılâ-i } \\
\text { Sahn }\end{array}$ & $\begin{array}{l}\text { Kilisli Mehmed } \\
\text { Kudsi Efendi }\end{array}$ \\
\hline $1226 / 1811$ & IV. & 13.Muhatap & $\begin{array}{l}\text { Mûsılâ-i } \\
\text { Sahn }\end{array}$ & $\begin{array}{l}\text { Kilisli Mehmed } \\
\text { Kudsi Efendi }\end{array}$ \\
\hline $1227 / 1812$ & IV. & 7.Muhatap & $\begin{array}{l}\text { Mûsılâ-i } \\
\text { Sahn }\end{array}$ & $\begin{array}{l}\text { Tirnovalı Müftizâde } \\
\text { Abdurrahim Efendi }\end{array}$ \\
\hline $1228 / 1813$ & IV. & 2.Muhatap & $\begin{array}{l}\text { Mûsılâ-i } \\
\text { Sahn }\end{array}$ & $\begin{array}{ll}\text { Çarşambalı Said } \\
\text { Efendi }\end{array}$ \\
\hline $1235 / 1820$ & II. & 1.Muhatap & $\begin{array}{l}\text { Mûsılâ-i } \\
\text { Süleymâniye }\end{array}$ & $\begin{array}{l}\text { Kütahyalı Mehmed } \\
\text { Efendi }\end{array}$ \\
\hline $1236 / 1821$ & I. & 13.Muhatap & $\begin{array}{l}\text { Mûsılâ-i } \\
\text { Süleymâniye }\end{array}$ & $\begin{array}{l}\text { Menteşeli Müftizâde } \\
\text { Abdürrahim Efendi }\end{array}$ \\
\hline $1237 / 1822$ & I. & 9.Muhatap & $\begin{array}{l}\text { Mûsılâ-i } \\
\text { Süleymâniye }\end{array}$ & $\begin{array}{l}\text { Kangirilı Şeyh } \\
\text { Abdullah Efendi }\end{array}$ \\
\hline $1238 / 1823$ & I. & 8.Muhatap & $\begin{array}{l}\text { Mûsılâ-i } \\
\text { Süleymâniye }\end{array}$ & $\begin{array}{l}\text { Menteşeli Müftizâde } \\
\text { Abdürrahim Efendi }\end{array}$ \\
\hline $1239 / 1824$ & I. & 6.Muhatap & $\begin{array}{l}\text { Mûsılâ-i } \\
\text { Süleymâniye }\end{array}$ & $\begin{array}{l}\text { Ekmekçizâde Hafız } \\
\text { Ahmed Efendi }\end{array}$ \\
\hline $1240 / 1825$ & I. & 4.Muhatap & $\begin{array}{l}\text { Mûsılâ-i } \\
\text { Süleymâniye }\end{array}$ & $\begin{array}{l}\text { Ekmekçizâde Hafız } \\
\text { Ahmed Efendi }\end{array}$ \\
\hline $1241 / 1826$ & I. & 2.Muhatap & Hâmise & $\begin{array}{l}\text { Ekmekçizâde Hafız } \\
\text { Ahmed Efendi }\end{array}$ \\
\hline $1242 / 1827$ & I. & 1.Muhatap & Dârülhadis & $\begin{array}{l}\text { Ekmekçizâde Hafız } \\
\text { Ahmed Efendi }\end{array}$ \\
\hline
\end{tabular}

\section{Abdülhayy Efendi (öl. 1339/1920)}

Kırımlı Kadı Hacı Murtaza Efendi'nin torunu, Hoca Abdülgaffar Efendi'nin oğludur. 1274 yılında Kırım'da doğdu. İlk tahsilini Kırım'da ve Rumeli'ndeki Hacıoğlu Pazarcığı'nda yaptı. Rumi 1279'da Pazarcık'ta medresede de bir süre eğitim gördü. Rumi 1283'te Varna Rüştiye'sinde Muallim Nâcî'den Arapça, Farsça, hüsn-i hat gibi dersler alarak bu

37 Mardin, Huzur Dersleri, 1/171 vd. 
S. GÜR / Crimean Ulama Who Participated in the Huzur Lessons and Publications of Quranic Commentary Texts of Mohammed Emin Efendi| 335 okulu da tamamladı. 1287'de İstanbul'a gelerek Uzunçarşı'daki Atik İbrahim Paşa Medresesi'ne kayıt oldu. Ardından naklini Şerif Hamidiyye Medresesi'ne aldırdı ve dersiâmdan mantıkçı Şehri Ahmed Efendi'den icâzet aldı. 1301 yılında ruûs imtihanını kazandı. 1302'de Süleymâniye Camii'nde müzâkereye başladı. 1316'da üç öğrenciye icâzet verdi. Sultan Abdülmecid Türbesi'nde Buhârîhanlık, Topkapı Ahmed Paşa Medresesi'nde müderris ve vaizlik yaptı. 1328' de Hareket-i Dâhil derecesiyle Sultan Bayezid Camii'nde müderrislik görevine getirildi. ${ }^{38}$ 1329-1338 yılları arasinda huzur derslerine muhatap olarak katıldı. 1339/1920 yılında vefat etti. ${ }^{39}$

Huzur Dersleri Katılım Tablosu. ${ }^{40}$

\begin{tabular}{|l|l|l|l|l|}
\hline Yıl (h/m) & Meclis & Görevi & Rütbesi & Mukarrir \\
\hline $1329 / 1911$ & VIII. & 4. Muhatap & $\begin{array}{l}\text { Serezli Eyyüb Sabri } \\
\text { Efendi }\end{array}$ \\
\hline $1330 / 1912$ & VII. & 15. Muhatap & $\begin{array}{l}\text { Midillili Muhammed } \\
\text { Emin Efendi }\end{array}$ \\
\hline $1331 / 1913$ & VII. & 2. Muhatap & $\begin{array}{l}\text { Midillili Muhammed } \\
\text { Emin Efendi }\end{array}$ \\
\hline $1332 / 1914$ & VI. & 8. Muhatap & $\begin{array}{l}\text { Aydoslu Sadullah } \\
\text { Efendi }\end{array}$ \\
\hline $1333 / 1915$ & IV. & 11. Muhatap & $\begin{array}{l}\text { Tirnovalı } \\
\text { Muhammed Hilmi } \\
\text { Efendi }\end{array}$ \\
\hline $1334 / 1916$ & II. & 14.Muhatap & $\begin{array}{l}\text { Kastamonulu Şükrü } \\
\text { Mustafa } \\
\text { Efendi }\end{array}$ \\
\hline $1335 / 1917$ & III. & 3. Muhatap & $\begin{array}{l}\text { Nasuh Efendizade } \\
\text { Mustafa Asım Efendi }\end{array}$ \\
\hline $1336 / 1918$ & III. & 7. Muhatap & $\begin{array}{l}\text { Batumlu Abdüllâtif } \\
\text { Efendi }\end{array}$ \\
\hline $1337 / 1919$ & II. & 11.Muhatap & $\begin{array}{l}\text { Kastamonulu Şükrü } \\
\text { Mustafa } \\
\text { Efendi }\end{array}$ \\
\hline $1338 / 1920$ & II. & 4. Muhatap & $\begin{array}{l}\text { Lüleburgazlı } \\
\text { Muhammed Eşref } \\
\text { Efendi }\end{array}$ \\
\hline
\end{tabular}

38 İlmiyye Salnamesi (Osmanlı İlmiyye Teşkilatı ve Şeyhülislamlar), haz. Seyit Ali Kahraman vd. (İstanbul: İşaret Yayınları, 1998), 109.

39 Mardin, Huzur Dersleri, 1/157; 2-3/1063-1064.

40 Mardin, Huzur Dersleri, 1/561 vd. 
336 | S. GÜR / Huzur Derslerine Katılan Kırım Uleması ve Muhammed Emin Efendi'nin Tefsir Metninin Neşri

\section{Ahmed Efendi (öl. 1205/1791 sonrası)}

Mardin, Topkapı Sarayı Müzesi'nden elde ettiği 1205 tarihli muhataplar listesinde huzur derslerine katılan bir Kırımlı Ahmed Efendi'ye de yer vermektedir. İlk tayin tarihini tespit edemediğini de belirtmektedir..$^{41} \mathrm{O}$ yılla ilgili verdiği detaylardan anlaşıldığına göre bu zât, 1205 yllında mukarrirliğini Bolulu el-Hac Mustafa Efendi'nin yaptığı VII. meclise 1. muhatap olarak katılmıştır. ${ }^{42}$ 1205-1224 yılları arasında bu derslere katılanlar tam olarak tespit edilemediğinden Ahmed Efendi'nin net olarak hangi yıllarda kaç kez bu derslere iştirak ettiği tespit edilememiştir.

Huzur Dersleri Katılım Tablosu. ${ }^{43}$

\begin{tabular}{|l|l|l|l|l|}
\hline Yıl (h/m) & Meclis & Görevi & Rütbesi & Mukarrir \\
\hline $1205 / 1791$ & VII. & 1.Muhatap & & $\begin{array}{l}\text { Bolulu el-Hac Mustafa } \\
\text { Efendi }\end{array}$ \\
\hline
\end{tabular}

\section{Ahmed Efendi (öl. 1247/1832 sonrası)}

Mardin, Ahmed Efendi'nin 1237 senesinde huzur dersleri muhataplığına tayin edildiğini ve 1248 yılında derslerden ayrıldığını belirtir. Ancak ayrılış nedenine dair bilgi vermez. ${ }^{44}$ Takip çizelgesinden anlaşıldığına göre Ahmed Efendi derslere 1237'de Hareket-i Dâhil rütbesi ile başlamış, 1243 yılı ve devamında Mûsılâ-i Sahn rütbesi ile dersleri takip etmiştir. ${ }^{45}$

Huzur Dersleri Katılım Tablosu. ${ }^{46}$

\begin{tabular}{|l|l|l|l|lr|}
\hline Y1l (h/m) & Meclis & Görevi & Rütbesi & \multicolumn{2}{|l|}{ Mukarrir } \\
\hline $1237 / 1822$ & VII. & 5.Muhatap & $\begin{array}{l}\text { Hareket-i } \\
\text { Dâhil }\end{array}$ & $\begin{array}{l}\text { Eğinli İbrahim } \\
\text { Efendi }\end{array}$ \\
\hline $1238 / 1823$ & VI. & 13.Muhatap & $\begin{array}{l}\text { Hareket-i } \\
\text { Dâhil }\end{array}$ & $\begin{array}{l}\text { Eğinli İbrahim } \\
\text { Efendi }\end{array}$ \\
\hline $1239 / 1824$ & VI. & 6.Muhatap & $\begin{array}{l}\text { Hareket-i } \\
\text { Dâhil }\end{array}$ & $\begin{array}{l}\text { Konevi Hacl } \\
\text { Seyyid Mustafa } \\
\text { Efendi }\end{array}$ \\
\hline
\end{tabular}

41 Mardin, Huzur Dersleri, 1/117.

42 Mardin, Huzur Dersleri, 1/168.

43 Mardin, Huzur Dersleri, 1/168.

44 Mardin, Huzur Dersleri, 1/127.

45 Mardin, Huzur Dersleri, 2-3/212, 230

46 Mardin, Huzur Dersleri, 1/205 vd. 
S. GÜR / Crimean Ulama Who Participated in the Huzur Lessons and Publications of Quranic Commentary Texts of Mohammed Emin Efendi| 337

\begin{tabular}{|l|l|l|l|l|}
\hline $1240 / 1825$ & VI. & 2.Muhatap & $\begin{array}{l}\text { Hareket-i } \\
\text { Dâhil }\end{array}$ & $\begin{array}{l}\text { Konyalı Hacı } \\
\text { Mustafa Efendi }\end{array}$ \\
\hline $1241 / 1826$ & V. & 10.Muhatap & $\begin{array}{l}\text { Hareket-i } \\
\text { Dâhil }\end{array}$ & $\begin{array}{l}\text { İmamzade Hafız } \\
\text { Muhammed Esad } \\
\text { Efendi }\end{array}$ \\
\hline $1242 / 1827$ & V. & 4.Muhatap & $\begin{array}{l}\text { Mûsılâ-i } \\
\text { Sahn }\end{array}$ & $\begin{array}{l}\text { İmamzade Hafız } \\
\text { Muhammed Esad } \\
\text { Efendi }\end{array}$ \\
\hline $1243 / 1828$ & IV. & 8.Muhatap & $\begin{array}{l}\text { Mûsılâ-i } \\
\text { Sahn }\end{array}$ & $\begin{array}{l}\text { İmamzade Hafız } \\
\text { Muhammed Esad } \\
\text { Efendi }\end{array}$ \\
\hline $1244 / 1829$ & IV. & 5.Muhatap & $\begin{array}{l}\text { Mûsılâ-i } \\
\text { Sahn }\end{array}$ & $\begin{array}{l}\text { İmamzade Hafız } \\
\text { Muhammed Esad } \\
\text { Efendi }\end{array}$ \\
\hline $1245 / 1830$ & III. & 12.Muhatap & $\begin{array}{l}\text { Mûsılâ-i } \\
\text { Sahn }\end{array}$ & $\begin{array}{l}\text { Ahıskalı Dersiam } \\
\text { Ahmed Efendi }\end{array}$ \\
\hline $1246 / 1831$ & III. & 12.Muhatap & $\begin{array}{l}\text { Mûsılâ-i } \\
\text { Sahn }\end{array}$ & $\begin{array}{l}\text { Ahıskalı Dersiam } \\
\text { Ahmed Efendi }\end{array}$ \\
\hline $1247 / 1832$ & III. & 8.Muhatap & $\begin{array}{l}\text { Mûsılâ-i } \\
\text { Sahn }\end{array}$ & $\begin{array}{l}\text { Ahıskalı Dersiam } \\
\text { Ahmed Efendi }\end{array}$ \\
\hline
\end{tabular}

\section{Ali Şücâî Efendi (öl. 1341/1922)}

1269/1853 yılında Bahçesaray'da doğdu. İlk tahsilini memleketinde yaptıktan sonra 1289 yılında İstanbul'a geldi. 1306 senesinde icâzet aldı. 1308 yılında açlan ruûs imtihanını kazanarak Süleymâniye Camii dersiâm ve müderrisleri arasına girdi. 1317'de İbtidâ-i Hâric ruûsa nail oldu. 1322' de Hareket-i Hâric derecesiyle Mehmed Ağa Medresesi ikinci müderrisliğine atandı. Dördüncü rütbeden Osmânî nişânı ve altın liyakat madalyası sahibi idi. 1333-1340 yılları arasında huzur derslerine muhatap olarak katıldı. 7 Ekim 1338 (1341/1922) yılında vefat etti. ${ }^{47}$ 1396 'da dersi Süleymâniye rütbesi ile takip etti. ${ }^{48}$

47 Mardin, Huzur Dersleri, 2-3/312, 1064.

48 Mardin, Huzur Dersleri, 1/596. 
338 | S. GÜR / Huzur Derslerine Katılan Kırım Uleması ve Muhammed Emin Efendi'nin Tefsir Metninin Neşri

Huzur Dersleri Katılım Tablosu. ${ }^{49}$

\begin{tabular}{|l|l|l|l|l|}
\hline Yll (h/m) & Meclis & Görevi & Rütbesi & Mukarrir \\
\hline $1333 / 1915$ & VII. & 10. Muhatap & & $\begin{array}{l}\text { Midillili Muhammed } \\
\text { Emin Efendi }\end{array}$ \\
\hline $1334 / 1916$ & V. & 4. Muhatap & & $\begin{array}{l}\text { Rizeli Osman Nuri } \\
\text { Efendi }\end{array}$ \\
\hline $1335 / 1917$ & V. & 8. Muhatap & & $\begin{array}{l}\text { Rizeli Osman Nuri } \\
\text { Efendi }\end{array}$ \\
\hline $1336 / 1918$ & V. & 11.Muhatap & & $\begin{array}{l}\text { Uşşakî Nasuh } \\
\text { Efendizade Mustafa } \\
\text { Asım Efendi }\end{array}$ \\
\hline $1337 / 1919$ & V. & 9.Muhatap & & $\begin{array}{l}\text { Arapgirli Hüseyin } \\
\text { Avni Efendi }\end{array}$ \\
\hline $1338 / 1920$ & IV. & 12.Muhatap & & $\begin{array}{l}\text { Batumlu Abdüllâtif } \\
\text { Efendi }\end{array}$ \\
\hline $1339 / 1921$ & IV. & 6.Muhatap & $\begin{array}{l}\text { Süleymâ } \\
\text { niye }\end{array}$ & $\begin{array}{l}\text { Batumlu Abdüllâtif } \\
\text { Efendi }\end{array}$ \\
\hline $1340 / 1922$ & III. & 11.Muhatap & & $\begin{array}{l}\text { Kastamonulu Mustafa } \\
\text { Şükrü Efendi }\end{array}$ \\
\hline
\end{tabular}

\section{Hasan Rüşdü Efendi (öl. 1311/1894)}

Mehmed Süreyyâ'nın, rüşdiye mekteplerinde senelerce muallim-i evvel, maarif müfettişi, birkaç ay kadar Dârulmuallimin müdürü, dersiâm ve müderris diye tanıttı̆̆ı, ilmî ve fazileti sayesinde halk arasında "Tatar Hoca" diye meşhur olup 13 Şaban 1311/1894 tarihinde vefat ettiğini söylediği Hacı Hasan Efendi, ${ }^{50}$ kanaatimize göre bazı kaynaklarda Hasan Rüşdü Efendi diye zikredilen zât olmalıdır. Nitekim Sicilli Ahval Defterleri üzerinde bir çalışma yapan Nuri Kavak'ın, Hocazâde el-Hâc Hasan Rüşdü Efendi hakkında verdiği bilgiler, Süreyyâ'nın Hasan Efendi ile ilgili verdiği bilgilerle örtüşmektedir. Hasan Rüşdü Efendi'nin tercüme-i hâl varakasındaki bilgiler özetle şu şekildedir: 1251/1835 senesinde Bahçesaray'ın Divan Köyü'nde doğdu. Bahçesaray ve Dersaadet'te Süleymâniye Dökmeci-i Evvel Medresesi'nde tahsil görerek icâzetname aldı. Uzun süre müderrislik

49 Mardin, Huzur Dersleri, 1/572 vd.

50 Süreyyâ, Sicill-i Osmânî, 2-3/190. 
S. GÜR / Crimean Ulama Who Participated in the Huzur Lessons and Publications of Quranic Commentary Texts of Mohammed Emin Efendi| 339 yaptı. Üçüncü rütbeden Mecidi, dördüncü rütbeden Osmani Nişan-1 zîşan madalyalarını elde etti. ${ }^{51}$

Mardin'in kaydettiğine göre 1290-1310 yılları arasında huzur derslerine muhatap olarak katılmış olup 1310 yılında vefat etti. ${ }^{52}$ Vefat tarihi ile ilgili 1310 ve 1311 seneleri zikredilmektedir. Ancak Mehmed Süreyyâ'nın vefatını, 13 Şaban 1311 şeklinde gün, ay, yıl olarak açıkça zikretmesi bu tarihin daha isabetli olabileceğine işaret etmektedir.

Huzur Dersleri Katılım Tablosu. ${ }^{53}$

\begin{tabular}{|c|c|c|c|c|}
\hline $\mathrm{Y}_{11}(\mathrm{~h} / \mathrm{m})$ & Meclis & Görevi & Rütbesi & Mukarrir \\
\hline $1290 / 1873$ & VIII. & 9.Muhatap & $\begin{array}{l}\text { Hareket-i } \\
\text { Dâhil }\end{array}$ & $\begin{array}{l}\text { Balıkesirli } \\
\text { Mustafa Münib } \\
\text { Efendi }\end{array}$ \\
\hline $1291 / 1874$ & VIII. & 7.Muhatap & $\begin{array}{l}\text { Hareket-i } \\
\text { Dâhil }\end{array}$ & $\begin{array}{l}\text { Balıkesirli } \\
\text { Mustafa Münib } \\
\text { Efendi }\end{array}$ \\
\hline $1292 / 1875$ & VII. & 9.Muhatap & $\begin{array}{l}\text { Hareket-i } \\
\text { Dâhil }\end{array}$ & $\begin{array}{ll}\text { İstanbullu } & \text { Hafız } \\
\text { Ahmed } & \text { Şakir } \\
\text { Efendi } & \\
\end{array}$ \\
\hline $1293 / 1876$ & VII. & 4.Muhatap & $\begin{array}{l}\text { Hareket-i } \\
\text { Dâhil }\end{array}$ & $\begin{array}{ll}\text { İstanbullu } & \text { Hafız } \\
\text { Ahmed } & \text { Şakir } \\
\text { Efendi } & \\
\end{array}$ \\
\hline $1294 / 1877$ & IV. & 7.Muhatap & $\begin{array}{l}\text { İbtidâ-i } \\
\text { Altmışlı }\end{array}$ & $\begin{array}{l}\text { Tikveşli Yusuf } \\
\text { Ziyaeddin Efendi }\end{array}$ \\
\hline $1295 / 1878$ & V. & 5.Muhatap & $\begin{array}{l}\text { İbtidâ-i } \\
\text { Altmışlı }\end{array}$ & $\begin{array}{l}\text { Vodineli Ömer } \\
\text { Hulusi Efendi }\end{array}$ \\
\hline $1296 / 1879$ & IV. & 11.Muhatap & $\begin{array}{l}\text { Hareket-i } \\
\text { Altmışlı }\end{array}$ & $\begin{array}{l}\text { Gümülcineli } \\
\text { Ahmed Asım } \\
\text { Efendi }\end{array}$ \\
\hline $1297 / 1880$ & IV. & 4.Muhatap & $\begin{array}{l}\text { Hareket-i } \\
\text { Altmışlı }\end{array}$ & $\begin{array}{l}\text { Gümülcineli } \\
\text { Ahmed Asım } \\
\text { Efendi }\end{array}$ \\
\hline
\end{tabular}

51 Nuri Kavak, Osmanlı Bürokrasisinde Görev Almış Kırım Kökenli Devlet Adamları (İstanbul: Has Matbaacilık, 2017), 155.

52 Mardin, Huzur Dersleri, 2-3/145.

53 Mardin, Huzur Dersleri, 1/419 vd. 
340 | S. GÜR / Huzur Derslerine Katılan Kırım Uleması ve Muhammed Emin Efendi'nin Tefsir Metninin Neşri

\begin{tabular}{|c|c|c|c|c|}
\hline $1298 / 1881$ & III. & 11.Muhatap & $\begin{array}{l}\text { Mûsıla-i } \\
\text { Süleymâniye }\end{array}$ & $\begin{array}{l}\text { Tikveşli Yusuf } \\
\text { Ziyaeddin Efendi }\end{array}$ \\
\hline $1299 / 1882$ & III. & 10.Muhatap & & $\begin{array}{l}\text { Gümülcineli } \\
\text { Ahmed Asım } \\
\text { Efendi }\end{array}$ \\
\hline $1300 / 1883$ & III. & 10.Muhatap & & $\begin{array}{l}\text { Gümülcineli } \\
\text { Ahmed Asım } \\
\text { Efendi }\end{array}$ \\
\hline $1301 / 1884$ & III. & 7.Muhatap & & $\begin{array}{l}\text { Gümülcineli } \\
\text { Ahmed Asım } \\
\text { Efendi }\end{array}$ \\
\hline $1302 / 1885$ & III. & 5.Muhatap & & $\begin{array}{l}\text { Gümülcineli } \\
\text { Ahmed Asım } \\
\text { Efendi }\end{array}$ \\
\hline $1303 / 1886$ & III. & 2.Muhatap & & $\begin{array}{l}\text { Gümülcineli } \\
\text { Ahmed Asım } \\
\text { Efendi }\end{array}$ \\
\hline $1304 / 1887$ & II. & 12.Muhatap & & $\begin{array}{l}\text { Tikveşli Yusuf } \\
\text { Ziyaeddin Efendi }\end{array}$ \\
\hline $1305 / 1888$ & II. & 10.Muhatap & & $\begin{array}{l}\text { Tikveşli Yusuf } \\
\text { Ziyaeddin Efendi }\end{array}$ \\
\hline $1306 / 1889$ & II. & 7.Muhatap & & $\begin{array}{l}\text { Gümülcineli } \\
\text { Ahmed Asım } \\
\text { Efendi }\end{array}$ \\
\hline $1307 / 1890$ & II. & 5.Muhatap & & $\begin{array}{l}\text { Gümülcineli } \\
\text { Ahmed Asım } \\
\text { Efendi }\end{array}$ \\
\hline $1308 / 1891$ & I. & 14.Muhatap & & $\begin{array}{l}\text { Gümülcineli } \\
\text { Ahmed Asım } \\
\text { Efendi }\end{array}$ \\
\hline $1309 / 1892$ & I. & 12.Muhatap & & $\begin{array}{l}\text { Gümülcineli } \\
\text { Ahmed Asım } \\
\text { Efendi }\end{array}$ \\
\hline $1310 / 1893$ & I. & 10.Muhatap & & $\begin{array}{l}\text { Gümülcineli } \\
\text { Ahmed Asım } \\
\text { Efendi }\end{array}$ \\
\hline
\end{tabular}


S. GÜR / Crimean Ulama Who Participated in the Huzur Lessons and Publications of Quranic Commentary Texts of Mohammed Emin Efendi| 341

\section{Selim Efendi (öl. 1260/1844)}

Hayatı hakkında fazla bilgi bulamadığımız bu zât, Kırımlı dersiâm Selim Efendi diye tanınmış olup 1258-1259 yıllarında huzur derslerine muhatap olarak katılmıştır. 11 Şaban 1260/1844 yılında vefat etmiştir. ${ }^{54}$ 1258 yılında, VIII. meclisin sekizinci muhatabı olarak katıldığ 1 dersi İbtidâ-i Hâric, 1259 yılında ise baş muhatap olarak katıldığı dersi Hareket-i Hâric rütbesi ile takip etmiştir. ${ }^{55}$

Huzur Dersleri Katılım Tablosu. ${ }^{56}$

\begin{tabular}{|l|l|l|l|l|}
\hline Y1l $(\mathrm{h} / \mathrm{m})$ & Meclis & Görevi & Rütbesi & \multicolumn{1}{|c|}{ Mukarrir } \\
\hline $1258 / 1842$ & VIII. & 8.Muhatap & İbtidâ-i Hâric & $\begin{array}{l}\text { Trabzonlu Numan } \\
\text { Efendi }\end{array}$ \\
\hline $1259 / 1843$ & VIII. & 1.Muhatap & $\begin{array}{l}\text { Hareket-i } \\
\text { Hâric }\end{array}$ & $\begin{array}{l}\text { Trabzonlu Numan } \\
\text { Efendi }\end{array}$ \\
\hline
\end{tabular}

\section{Şerafeddin Şerif Efendi (öl. 1331/1913)}

Ahmed Efendi'nin oğlu olup Kırım'da doğdu. İlk tahsilini memleketinde yaptıktan sonra İstanbul'a geldi. Fatih Camii'nde tahsilini tamamlayıp icâzet aldı. 17 Safer 1331/1913 yılında Fatih Camii'nde dersiâm olarak görev yaparken vefat etti. ${ }^{57}$ 1317-1330 yılları arasında huzur derslerine muhatap olarak katıld1..$^{58}$

Huzur Dersleri Katılım Tablosu. ${ }^{59}$

\begin{tabular}{|l|l|l|l|l|}
\hline Y1l (h/m) & Meclis & Görevi & Rütbesi & Mukarrir \\
\hline $1317 / 1900$ & VIII. & 8.Muhatap & $\begin{array}{l}\text { Tosyalı İsmail Zühdü } \\
\text { Efendi }\end{array}$ \\
\hline $1318 / 1901$ & VIII. & 3.Muhatap & $\begin{array}{l}\text { Sinoplu Hafız } \\
\text { Ebubekir Lütfi Efendi }\end{array}$ \\
\hline $1319 / 1901$ & VII. & 6.Muhatap & & $\begin{array}{l}\text { Ankaralı Mustafa } \\
\text { Fevzi Efendi }\end{array}$ \\
\hline
\end{tabular}

54 Mardin, Huzur Dersleri, 1/135.

55 Mardin, Huzur Dersleri, 1/292-295.

56 Mardin, Huzur Dersleri, 1/292 vd.

57 Sadık Albayrak, Son Devir Osmanlı Uleması (İstanbul: Millî Gazete Yayınları, 1980), $4 / 332$.

58 Mardin, Huzur Dersleri, 1/154.

59 Mardin, Huzur Dersleri, 1/517 vd. 
342 | S. GÜR / Huzur Derslerine Katılan Kırım Uleması ve Muhammed Emin Efendi'nin Tefsir Metninin Neşri

\begin{tabular}{|l|l|l|l|l|}
\hline $1320 / 1902$ & VI. & 11.Muhatap & & $\begin{array}{l}\text { Tokatl Hoca Ahmed } \\
\text { Efendizade Ahmed } \\
\text { Nureddin Efendi }\end{array}$ \\
\hline $1321 / 1903$ & VI. & 7.Muhatap & $\begin{array}{l}\text { Tokatlı Hoca Ahmed } \\
\text { Efendizade Ahmed } \\
\text { Nureddin Efendi }\end{array}$ \\
\hline $1322 / 1904$ & VI. & 2.Muhatap & & Moralı Murtaza Efendi \\
\hline $1323 / 1905$ & V. & 9.Muhatap & $\begin{array}{l}\text { Sinoplu Ebubekri Lütfi } \\
\text { Efendi }\end{array}$ \\
\hline $1324 / 1906$ & V. & 9.Muhatap & $\begin{array}{l}\text { Sinoplu Ebubekri Lütfi } \\
\text { Efendi }\end{array}$ \\
\hline $1325 / 1907$ & V. & 2.Muhatap & Moralı Murtaza Efendi \\
\hline $1326 / 1908$ & IV. & 10.Muhatap & & $\begin{array}{l}\text { Sinoplu Ebubekri Lütfi } \\
\text { Efendi }\end{array}$ \\
\hline $1327 / 1909$ & III. & 14.Muhatap & & $\begin{array}{l}\text { Ödemişli } \\
\text { Fehmi Efendi }\end{array}$ \\
\hline $1328 / 1910$ & III. & 12.Muhatap & $\begin{array}{l}\text { Nasuh Efendizade } \\
\text { Mustafa Asim Efendi }\end{array}$ \\
\hline $1329 / 1911$ & III. & 7.Muhatap & & $\begin{array}{l}\text { Tirnovalı Muhammed } \\
\text { Hilmi Efendi }\end{array}$ \\
\hline $1330 / 1912$ & III. & 2.Muhatap & $\begin{array}{l}\text { Tirnovalı Muhammed } \\
\text { Hilmi Efendi }\end{array}$ \\
\hline
\end{tabular}

\section{Kırımlı Muhammed Emin Efendi'nin Huzur Dersi Tefsir Metni}

Huzur dersleri literatürü konusunda çalışma yapan bazı araştırmacılar, muhtemelen tespit edilebilen metinlerden hareketle günümüze ulaşan en eski tarihli notların Sultan II. Mahmut devrine ait olduğunu ifade etmişlerdi. ${ }^{60}$ Sultan II. Mahmut dönemindeki ilk kayıt da 1238 yılı Ramazan'ında Kırımlı Muhammed Efendi'nin mukarrirliğini yaptığ1 III. meclise aitti. Bu durumda günümüze ulaşan en eski huzur dersi takrir metninin Kırımlı Muhammed Efendi'ye ait olduğu söylenebilirdi. Tarih itibari ile ona en yakın metin ise ayn yılın Ramazan'ındaki VI. meclise aitti. Mukarrirliğini Eğinli İbrahim Efendi'nin yaptığ 1 bu mecliste Âl-i İmrân sûresinin 145. âyeti tefsir

60 Kara, “Osmanlı'da Huzur Dersleri Geleneği Literatürü”, 531. 
S. GÜR / Crimean Ulama Who Participated in the Huzur Lessons and Publications of Quranic

Commentary Texts of Mohammed Emin Efendi| 343

edilmişti. En eski tarihli diğer metin ise 1266 yılına aitti. Faşlı Süleyman Halid Efendi'nin mukarrirliğini yaptığı kuvvetle muhtemel olan bu derste Maide sûresinin birinci âyeti tefsir edilmiştir. ${ }^{61}$

Ancak yapılan yeni çalışmalar bu tarihlerden önce de huzur dersleri ile ilgili bazı kayıtların tutulduğunu ortaya koymaktadır. Nitekim, Recep Arpa'nın tespitine göre, Topkapı Sarayı Müzesi Türkçe Yazmaları Emanet Hazinesi, nr. 888'de, mukarrir Ahmed el-Giridî́nin 1177 yılında yapmış olduğu huzur dersine ait 13 varaklık bir risale bulunmaktadır. ${ }^{62} \mathrm{Bu}$ durumda söz konusu metin, huzur derslerine dair şu ana kadar tespit edilebilen en eski tarihli metin olmalıdır. En eski tarihli diğer bir metin ise 1200/1786 yılında, Fâtiha sûresinin tefsir edildiği huzur derslerinin bir özeti mahiyetinde olan Hulâsatü'lMukarrirîn isimli bir risaledir. Süleymaniye Yazma Eser Kütüphanesi, Kasidecizade, nr. 756m'de bulunan bu risale Mehmet Akif Alpaydin tarafından çalışılmıştır. ${ }^{63} \mathrm{Bu}$ durumda Kırımlı Muhammed Efendi'nin takrir metni, huzur derslerine dair günümüze ulaşan en eski tarihli üçüncü metin olmalıdır. Ancak yeni çalışmalar neticesinde daha eski tarihli metinlere ulaşılabileceği gerçeği de göz ardı edilmemelidir.

Yukarıda mukarrirler başlığı altında ele alınan Muhammed Efendi, 1236-1242 yılları arasında toplam yedi huzur dersini takrir ettiği halde sadece 1238 yllındaki ders takrir metnine ulaşılabilmiştir. Inceleyecek olduğumuz 13 varaklık bu metin, İstanbul Üniversitesi Kütüphanesi, (Yıldız Sarayı Kütüphanesi Eserleri), Türkçe Yazmalar Bölümü nr. 7297'de yazma halinde olup dili Türkçe'dir. Âl-i İmrân sûresinin 139-142. âyetlerinin tefsir edildiği eser, mukaddimeden anlaşıldığına göre Sultan II. Mahmud devrinde icra edilen huzur derslerinin III. meclisine aittir. Eserin mukaddimesinde müellif adı "Muhammed Emin bin Es'ad" şeklinde geçmekte olup yazarın Kırımlı olduğuna dair bir bilgi yer almamaktadır. Telif tarihi ile ilgili herhangi bir kayıt da yoktur. Ancak eserin Kırımlı Muhammed Efendi'nin ders takriri olduğu ve $1238^{\prime}$ de yazıldığı Mardin'in şu ifadelerden anlaşılmaktadır: “H. 1223-1255'e rastlayan Sultan II. Mahmud devrinde

61 Mardin, Huzur Dersleri, 2-3/1106.

62 Arpa, “Huzur Derslerinde Kâdî Beydâvî Tefsiri mi Takip Edilirdi?”, 104.

63 Mehmet Akif Alpaydın, “Hulâsatü'l-Mukarrirîn: Huzur Dersi'nde Fâtiha Tefsirinden Süzülenler", Uludă̆ Üniversitesi İlahiyat Fakültesi Dergisi 27/1 (2018), 193-210. 
344 | S. GÜR / Huzur Derslerine Katılan Kırım Uleması ve Muhammed Emin Efendi'nin Tefsir Metninin Neşri

III. Meclis Mukarriri Muhammed (Emin) Efendi diye yalnız H. 1238'de Kırımlı Muhammed Efendi bulunduğuna, H. 1251'de toplanan "Sudûr Meclisi"nde Çerkeşli Muhammed Efendi Âl-i İmrân sûresinin 200 üncü âyetini takrir ettiğine ve H. 1200-1251 arasinda bir yılda ortalama 10 âyet takrir olunduğuna göre 1238 Ramazanı, III. Meclis Mukarriri Kırımlı Muhammed Efendi'nin takriri olmak gerekir." 64

\section{Metnin Kaynakları}

Huzur derslerinde temel kaynağın Kâdî Beydâvî'nin Envâru'ttenzîl adlı tefsiri olduğu bilinen bir husustur. Ancak şüphesiz ulema, bu kaynağa ilaveten başka eserlerden de faydalanmıştır. Muhammed Efendi'nin de esas kaynağ Envâru't-tenzîl olmakla birlikte istifade ettiği başka kaynaklar da vardır: Kâdî, Allâme Kâdî ifadeleriyle Envâru'ttenzîl' den, ${ }^{65}$ Keşşâf, ifadesiyle Zemahşerî'nin (öl. 538/1144) tefsirinden, ${ }^{66}$ Sahib-i Kebîr Allâme Râzî, Sahib-i Kebîr ifadeleriyle Fahrüddîn erRâzî'nin Mefâtîhu'l-gayb (öl. 606/1210) adlı tefsirinden,, Ebüssuûd'un (öl. 982/1574) İrşâdü'l- 'akli's-selîm'inden, ${ }^{68}$ Kadı İyâz'ın Şifâ-i Şerif adlı eserinden, ${ }^{69}$ Rûhu'l-beyân sâhibi Hakkı kuddise sirruhu ifadesiyle ${ }^{70}$ Bursevî'nin (öl. 1137/1725) tefsirinden faydalanan müellif, eser adı zikretmeksizin Zeccâc (öl. 311/923), İmam Ferrâ (öl. 207/822), ${ }^{71}$ İbn Kemâl (öl. 940/1534) 72 $^{7 i b i}$ âlimlerden, ayrıca ulemâ-i Basra ve Kûfiyyûn, $^{73}$ bazıları, bazı müfessirin ${ }^{74}$ gibi ifadelerle daha başka kaynaklardan da faydalanmıştır.

\section{Metnin Muhtevasi}

Türkçe olarak telif edilen risalede bir mukaddime yer almaktadır. Müellif, bu mukaddimeye besmele, hamdele ve salvele ile başladıktan

64 Mardin, Huzur Dersleri, 2-3/1106.

65 Kırımlı Muhammed Emin b. Esad Efendi, Âl-i İmrân Sûresi 139-142 Âyetlerin Tefsiri, İstanbul Üniversitesi Kütüphanesi (Yıldız Sarayı Kütüphanesi Eserleri), Türkçe Yazmalar Bölümü, nr. 7297, vr. 5a, 5b, 7b.

66 Kirıml, vr. 3a.

67 Kirıml, vr. 4b, 5b.

68 Kirımli, vr. 7b.

69 Kirıml, vr. 6a.

70 Kirıml, vr. 9a.

71 Kirıml, vr. 10a.

72 Kirımli, vr. 5b.

73 Kirıml, vr. 12a.

74 Kirımli, vr. $4 b, 5 b$. 
S. GÜR / Crimean Ulama Who Participated in the Huzur Lessons and Publications of Quranic Commentary Texts of Mohammed Emin Efendi| 345 sonra kendisini Muhammed Emin bin Es'ad diye tanıtmıştır. Ardından devrin padişahı Sultan II. Mahmud'a övgüler dizip dualar etmiştir. Devaminda huzur-1 humâyun derslerine atıfta bulunarak Ramazan ayında icra edilecek bu dersin III. meclise ait olduğunu, gerekli mütalaaları yaptıktan sonra takririne ve tahririne başladığını belirterek mukaddimeyi sonlandırmıştır. ${ }^{75}$ Müellifin mukaddimede kullandığı dil tefsir bölümüne göre oldukça ağırdır.

Müellifin tefsir edeceği âyetler Uhud Savaşı'nı konu edinmektedir. $\mathrm{Bu}$ yüzden müellif, âyetlerin tefsirine geçmeden önce Uhud Savaşı'ndaki tarihi süreci aktarmaktadır. Bu bağlamda Mekkeli müşriklerin Bedir Gazvesi'nde ağır bir yenilgi aldıklarından ve aldıkları bu yenilginin intikamını almak için hazırlık yapmaya başladıklarından bahseder. Ebû Süfyân idaresinde Şam tarafından gelen kervan Bedir'de müslümanların hücumundan kurtulup Mekke'ye salimen ulaşınca, Abdullah b. Rabia, Saffan b. Ümeyye gibi Mekke'nin önde gelenleri ile savaşta yakınlarını kaybedenlerin kervandan elde ettikleri bütün kârlarını intikam için harcamaya karar verdiklerini ifade eder. Hz. Peygamber'in amcası Abbas'ın, müşriklerin bu hazırlıklarını Resûlullah'a bildirdiğini, bunun üzerine Medine'de de hazırlıklar yapıldığını aktarır. İslâm ordusunun 1000 asker ile yola çıktı̆̆ını ancak 300 kişilik bir gurubun ordudan ayrılıp geri dönmesi ile 700 kişi kaldıklarını, müşriklerin ise 3000 kişi olduklarını bildirir. İki ordunun Uhud dağı civarındaki mücadelelerini ve bu esnada cereyan eden hadiseleri ele alır. Hz. Peygamber'in Abdullah b. Cübeyr kumandasındaki elli okçuyu Uhud dağının karşısındaki bir tepeye yerleştirdiğini ve onlara buradan hiçbir şekilde ayrılmamaları gerektiğini tenbihlediğini, ancak ilk anda Müslümanların baskın gelip düşmanı savaş alanından kovalamaya başlamaları üzerine kesin zafer kazandıkları düşüncesiyle ganimet toplamaya yöneldiklerini, bunun üzerine okçuların çoğunun yerlerini terk ettiklerini, durumu fark eden müşriklerin bir fırsat bulup müslümanları arkadan çevirerek saldırıya geçtiklerini ve neticede İslâm ordusundan Abdullah b. Cübeyr, Mus'ab b. Umeyr, Hamza gibi çok sayıda önemli ismin şehit düştüğünü zikreder. İşte bu olaylar üzerine Yüce Allah'ın Hz. Peygamber'i ve

75 Kirimli, vr. 1b-2a. 
346 | S. GÜR / Huzur Derslerine Katılan Kırım Uleması ve Muhammed Emin Efendi'nin Tefsir Metninin Neşri

ashabını teselli etmek, kalplerini kuvvetlendirmek için Âl-i İmrân sûresinin 139. âyetini indirdiğini ifade eder. ${ }^{76}$

Bu âyetin tefsiri bağlamında; müşriklerin Bedir'deki akıbetlerinin kötü olmasına ve itikatlarının bâtıl olmasına rağmen savaşa hazırlık noktasında ciddiyet ve gayret sarfettiklerini, müminlerin davalarının ise hak olduğunu, dolayısıyla iman ve itikatları gereği asla gevşeklik ve zafiyet göstermemeleri gerektiğini Razi'ye de atıfta bulunarak ifade eder. Devamındaki âyette yer alan "karh/قَرْح" lafzındaki kaf harfinin zamme ve fetha ile okunuşuna dikkat çekerek bu okunuşun manaya etkisine temas eder. ${ }^{77}$ Risalenin devamında da zaman zaman kıraat vecihlerine yer verdiği görülür.

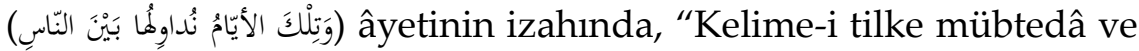
el-eyyâm lafz-1 şerîfî sıfat ve nüdâvilühâ mübtedânın haberi, yâhûd eleyyâm haber nüdâvilühâ hâl olmak muhtemeldir" ifadeleri ile gramer konularına girdiği görülür. Aynı âyeti izah ederken, bazı müfessirlerin âyetin manasını "bazen bir kavme zafer gösteririz, bazen öbürüne" şeklinde tefsir ettiklerini, bazılarının ise zaferin kâfirlere lâyık olmadığı düşüncesiyle bu manayı caiz görmediklerini ifade eder. Ancak kendisinin birinci manayı tercih ettiğini şu sözlerle beyan eder: "Ezcümle, eğer cemi vakitte mihnet ve meşakkat küffâr üzerine vâki olsa imanın hakikati ve sâir edyanın bâtıl oldığına ilm-i zarûrî hâsıl olub teklif-i şer'î ve sevâb ve 'ikâb ve şehâdet cümlesi bâtıle olur idi. Bu ecilden Hak sübhanehu ve te âlâ mihneti bazan İslâm'a ve bazan küffara teslid buyurd1."78

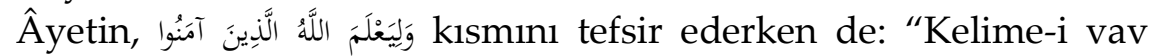
harf-i atıfe, lâm harf-i cerr ya mukaddem ya muahher bir fiile müteallikdir" ifadeleriyle dille ilgili açıklamalar yaptığı görülür. Yine bu âyet çerçevesinde ehl-i sünnet kelamcıları ile mu'tezile arasındaki "Allah'ın ilmi" konusunda cereyan eden tartışmaya kısaca temas eder ve "tâife-i mu'tezile gibi zâhir-i âyet ile amel caiz değildir" diyerek onların görüşlerini reddeder.79 واللَُّ لا يُحِبُُ الظّالِِِينَ ibaresini açıklarken "Bu kavl-i şeriff bir cümle-i mu teriza olup mâ kablinin mazmununu takrir içün sevk buyuruldı. Lâkin mehabbeti nefy buğz ve gazabdan kinayedir.

\footnotetext{
76 Kirımll, vr. 2b-4a.

77 Kirımli, vr. 4b.

78 Kirıml, vr. 5b.

79 Kirımlı, vr. 6b-7a.
} 
S. GÜR / Crimean Ulama Who Participated in the Huzur Lessons and Publications of Quranic

Commentary Texts of Mohammed Emin Efendi| 347

Ve zâlimîne îkâ'ı mukabilinde olan zevât-1 âdiline muhibban zâlimîne ta 'rîzdir" cümleleri ile belagat konularına girdiği görülür. ${ }^{80}$

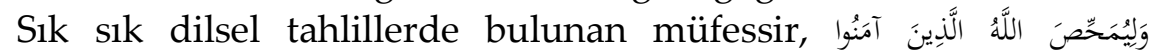
âyetinin tefsirinde de risalenin hacmine göre detaylı açıklamalar yapar. "Nazm-1 şerîf-i rabbânîde vâki kelime-i vav harf-i atıfe ve lâm harf-i cerr, yumahhısa bâb-1 tef' îlden fi 'li muzâri en-i mukadder ile mansub ve yettehize minküm kavl-i şerifi üzerine matufdur" sözleri ile cümledeki sarf ve nahiv kaidelerine işaret ettikten sonra matufun aleyhde lâm harfinin neden bulunmadığını sorgular ve bunun hikmetlerini ve manaya etkisini mukayeseli bir şekilde anlatır. kَ kelimesinin lügat anlamları üzerinde durur. Galip gelmenin kafirler için olursa hangi anlamlara geleceğini, müminler için olursa ne mana ifade edeceğini açıklar. Bunun gibi nimet ve musibetin mümine isabet etmesi ile kâfire isabet etmesinin nedenlerini ve aralarındaki farkları rivâyetlerden de faydalanarak beyan eder. ${ }^{81}$

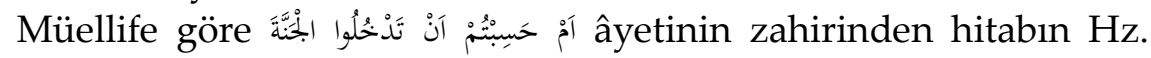
Peygamber'in emrine muhalefet edenlere ve bir de Uhud'da perişanlığa sebep olanlara yönelik olduğu anlaşılır. Yine bu ifadelerle Peygamber'in emrine karşı gelen kimselerin azarlandığı ve kınandığ1 ortaya çıkar. Ayrıca Allah yolunda cihad etmeden ve cihadın gerektirdiği yaralanma, acı, meşakkate tahammül gibi sıkıntılara katlanmadan ve bunlara katlananlarla katlanmayanlar ayırt edilmeden inananların cennet hayali kurmamaları gerektiğine işaret edilir. Âyetteki مُ lafzına yüklenen görev ve anlamları, müfessir ve dilcilerden yaptğı nakillerle ele alıp değerlendirir. Bu konuda akıllara gelebilecek muhtemel sorulara cevap arar. Devamında gelen لَّ lafzından hareketle vo varasındaki farka temas eder. Motamot çevrildiğinde "henüz Allah bilmeden..." manasına gelen âyetin ilgili kısmının aslında "Allah içinizden cihat edenleri belli etmeden ve sabredenleri ortaya çıkarmadan" manasına olduğunu çeşitli izahlar yaparak ortaya koymaya çalışır. Son olarak birkaç satırla meramını özetleyerek tefsirini sonlandırır. ${ }^{82}$ Müellifin âyetleri daha çok filolojik açıdan tahlil ettiği, ilm-i kelâm konularına ağırlık verdiği, yeri

\footnotetext{
80 Kirimli, vr. 7b.

81 Kirimli, vr. 7b-9b.

82 Kirımli, vr. 9b-13a.
} 
348 | S. GÜR / Huzur Derslerine Katılan Kırım Uleması ve Muhammed Emin Efendi'nin Tefsir Metninin Neşri

geldikçe âyetlerin siyer, kıraat vb. ilimlere taalluk eden vecihlerini de ele aldığı görülür.

\section{Sonuç}

$\mathrm{Bu}$ çalışmadaki tespitlerimize göre, oldukça üst düzey ilmi bir faaliyet olan huzur derslerine, iki mukarrir sekiz muhatap olmak üzere Kırımlı on âlim katılmıştır. Bunlardan Abdülhalim Efendi 1198-1202 yılları arasında mukarrir, Muhammed Emin Efendi 1224-1235 yılları arasinda muhatap, 1236-1242 yılları arasında mukarrir olarak huzur dersleri hocalığı yapmıştır. Muhammed Emin Efendi ile Abdullah Efendi aynı tarihler arasinda (1224-1242), bazen aynı meclislerde bu derslerde bulunmuşlardır. 1290-1310 yılları arasında toplam 21 kez dersleri muhatap olarak takip eden Hasan Rüşdü Efendi, bu derslere en fazla katılan isim olmuştur. Bu veriler şu ana kadarki kayıtlardan hareketle elde edilmiştir. Bazı yıllarla ilgili hiçbir kayıt günümüze ulaşmadığından derslere katılan toplam kişi sayısı ile meclis sayısı konusunda verilen bilgilere ihtiyatlı yaklaşılmalıdır. Yeni belgelere ulaşıldıkça bu rakamların değişme olasılığı vardır.

$\mathrm{Bu}$ çalışmada dikkat çeken önemli bir husus, Kırım ulemasının tamamının 1783 Rus işgalinden sonra huzur derslerine katıldığının anlaşılmasıdır. Onların hayat hikâyelerine bakıldığında önemli bir kısmının ilk tahsillerini Kırım'da yaptıkları, daha sonra İstanbul'a geldikleri ve başta ilmiye sınıfının en prestijli görevi olan huzur derslerine katılmak olmak üzere, Osmanlı Devleti'nin önemli kademelerinde görev yaptıkları da görülmektedir. Bu durum, OsmanlıKırım münasebetlerinin işgalden sonra da yoğun bir şekilde sürdüğ̈̈nü ortaya koyduğu gibi Kırım ulemasının ilmiye sınıfındaki konumunu göstermesi bakımından da dikkate değerdir.

Huzur derslerinin muhtevasına dair yegâne kaynak, takrir ve müzâkere metinleridir. Ancak bu metinlerden günümüze ulaşanlar ve bilhassa eski tarihli olanlar oldukça azdır. Bu makalede incelenen Muhammed Emin Efendi'nin metni de bunlardan biridir. 1238 senesinde icra edilen huzur derslerinin III. meclisinde müzâkere edilen Âl-i İmrân sûresinin 139-142. âyetlerinin tefsir edildiği bu eser de huzur derslerinin muhtevasına ve âyetlerin tefsir metoduna dair bazı fikirler vermektedir. Sadece müzâkere metninin yer aldığı eserde, tıpkı temel kaynak olarak kullanılan Beydâvî'nin Envâru't-tenzîl'i ile Fahruddîn er-Râzî'nin Mefât îh'inde olduğu gibi, rivayet tefsir yöntemi de kullanılmış olmakla 
S. GÜR / Crimean Ulama Who Participated in the Huzur Lessons and Publications of Quranic Commentary Texts of Mohammed Emin Efendi| 349 birlikte dirâyet yöntemine ağırlık verildiği görülmektedir. Bu bağlamda âyetler âyetle, hadisle, selef âlimlerinin görüşleri ile tefsir edildiği gibi ekseriyetle geniş dilsel tahlillere, kelâmi tartışmalara, kıraatların manaya etkisine ve benzeri konulara girilmiştir. Anlaşıldığı kadarıyla klasik dönem tefsir metinlerinde de sıkça kullanılan bu yöntem huzur dersleri mukarrirleri tarafından da benimsenmiş ve uygulanmıştır. 
350 | S. GÜR / Huzur Derslerine Katılan Kırım Uleması ve Muhammed Emin Efendi'nin Tefsir Metninin Neşri

\section{EK: Tefsir Metninin Transkripsiyonu ${ }^{83}$}

Bismillāhịrraḥmānirrahịm.

[1b] el-Ḥamdü lillāhi'l-ležī meḥhașa zünūbe'l-mü'minīne bismihi'lguufrān ve meḥhaḳa āsāāra'l-küfri ve'ş-şekki bi inzāli'l-Kur'ān. Ve'ṣ-ṣalātü ve's-selāmü 'alā Muḥammedini'n-nebiyyi'l-ležī haș̣̦a bihi șurāḥa'lmu 'cizāt ve neșṣa 'alā hātemiyyetihi fi'r-risāleti bi'l-āyāti'l-beyyināt ve 'alā ālihī ve aṣhạāhihi'l-lez̄ine hüm mecme'u biḥāri'l-'ulūm ve żıyāi'lhulūm fi'l-fühūm.

Emmā ba 'd: Bu bende-i ḳalīleti'l-biżā'ati Muhammed Emīn bin Es'ad ol şāh-1 İslām ve nūr-i çeşm-i cemī'i zevi'l-efhām ve müşārun ileyhi bi'l-benāni beyne ehli'l- 'irfān ve inşa?-nümā-yi cihān Ġāzī Sulțān Maḥmūd Ḩān edāmellāhu 'umrehu ve iclālehu [2a] ilā āhiri'z-zemān ve nihāyeți' d-deverān efendimiz ḥażretlerīniñ āşiyāne-i feyż-1 firāvān ve naṣb-1 'ayni 'āliyān olan Sarāy-1 Hümāyūn iḳbāl-nümūnlarında amed-i medīd ve 'ahd-i be 'îddenberü ve evḳāt-ı hāliye-i tahṣîl-i 'ulūme șarf birle nihāl-i iştiḡāl-i devām-1 bendegi inbāt-1 semerāt-1 ma' lūmāta isti'dādı fi'l-cümle zāhir olmağla meyve-i nūr-i seyyide-i bāg fikret-i ceyyide ve vaż i țabaḳçe-i beyān ve taḳdīm-i pişgāh-1 zulli zalīli'r-raḥmān ītmege vesīle cūyān iken māh-1 ṣıām-1 mubārekede hụużūr-1 hümāyūn-1 fāiżi'nnūr mulūkānede, tefsīr ve ḳırāati mev'ūd ve melḥuz olan ders-i sāâlise müteșādif āyet-i kerīme-i rabbānī ḥavșala-i idrāḳ-i kemterānemiñ ihātạa ìdecegi miḳdārı muṭāla'a ve netīcesinde hāame-i 'acz ile haāifen ve rāciyen taḳrīr ve tahrīine şuru' olundı. Ve billāhi't-tevfîk.

Hafī degildir ki cemīì-i Kur'ān-ı Kerīm mā ḳabline irtibāt-ı ạ̣sen ile mürtebịt olmag̉la sebeb-i nüzūli ba'de'l-beyān zikr ve beyānı [2b] mevkūufun 'aleyh olān āyet-i kerīmeniñ tefsīriyle bed' olunmaḳ muvāfıḳ1 re'y-i hakịir olmuşdur. Ba'żi vekāyi '-nüvis 'ahd-i hümāyūn-i Peyġamberī olan kimesneler şu vechile rişte-i takrīre ferāid rivāyeti naẓm ītmişlerdir ki Ḥaḳ subḥanehū ve te ālā ḥażretleri küffār-1 Ḳureyşi Bedir gününde menkūb ve meksūr īdūb ḳatl ve üserāiyetten hadd-i halāṣa vuṣul bulān kimesneler Mekke'ye mürāca at ìdūb Ebū Süfyān ile cānib-i Şām'dan vārid olān ḳāfilei sālimen Dārunnedve'de maḥzūnen bulmuşlar ve eşrāf-ı Kureyş ḩușūsen Abdullah bin Rabī'a ve Șafvān bin Ümeyye ve 'İkrime bin Ebū Cehl ve yevm-i Bedir'de ābā' ve ihvvānı

$83 \mathrm{Bu}$ transkripsiyonda eserin bilinen tek nüshası olan ve İstanbul Üniversitesi Kütüphanesi (Yıldız Sarayı Kütüphanesi Eserleri), Türkçe Yazmalar Bölümü, 7297 numarada kayıtlı bulunan nüsha esas alınmıştır. 
maḳtūl olan ruesā ittifāḳ ītmişler ki bu kārbāndan ḥāṣıl olan fāidei Muhammed'den aḩz-i intiḳām içūn bir ceyşe șarf ītmege rāżıyuz ve hāṭ̂rımız meblag்-1 mezbūrīn bu mașrafa șarfine ḩoşhāldir şāyed ki ateş-i gayẓımız bununla munțafī olā deyūb meyānelerinden Ebū Süfyan re'y-i mezkūrīn icrāsında ebnā-yı 'Abbülmuțtalib benimle bile deyū mühürzed ittifaḳnāme [3a] olaraḳ ḳabāil-i sāirelerden bu ra'y-i bed-fercāma nīce kimesneleri ittibā' ${ }^{\prime}$ derek tertīb-i leşker ve āvāze-i gurūr ile mukātele niyetin çıḳtılar def'aten Abbās bin el-Muṭtalib aḥāl-i Kureyş’i kemmiyyet-i a'dād-1 ceyşi müş ir bir mektūb-1 belāgat maṣụūbla bir ferdi cenāb-1 hayri'l-beşer cānibine irsāl ̄̄dūb Mescid-i Kubā'da iken peyāmnāme-i 'Abbās'1 resīde-i cāy-1 vuṣūl ve mefhūmi ehāli-i Medīne'niñ ma 'lūmi olub Rasūl-i āhiri'z-zemān cānib-i āherden tefaḥụus buyurub ahbār-1 'Abbās'a tevāfuḳ ītmekle aṣhāb-ı kirām teheyyü-i sefer îtdiler. Rivāyet-i Keşşāf ve sāirlere göre hicret-i nebeviyyeniñ sene-i sāâlis-i Şevvāl'iniñ on ikinci yevmi'l-erba 'ade huyūl-i müşrikīn cebel-i Uḥud'1 mażrib-i hiyām iḳāmet eylediler ve cebel-i mežkūr civār-1 Medīne'de vāḳi cibāl-i āherden munfaṣıl ve munḳațı ve mütevaḥhid olmag̉la Uhud tesmiye ḳılınmışdır. Ve'l-ḥāṣıl mạ̣būb-i Hudā imtis̄ālen li emrillāh fermān buyurub üç livā naṣb ve cānib-i Uhud'a neḥżat ve 'az̄imet buyurdilar.

[3b] 'Asākir-i İslām 'alā rivāyetin bin ve rivāyet-i āḩere göre doḳuz yüz nefer ve leşker-i müşrikīn üç biñ idi. Rasūl-i kāināt șallellāhu 'aleyhi ve sellem efendimiz esnā-yi rāhda Şeyhayn nām mahalle vurūd buyurduḳlarında mechūlü'l-ḥāl olan üç yüz kimesneleri giru ircā' buyurdılar. 'Asker-i İslām yedi yüz bāḳī ḳaldı. Cebel-i mežkūr havline vāṣıl olunduḳda tertībāt ve tedbīrāt-1 ḥarbiye huuṣūsuna diḳḳat buyurulub ol maḳāmda bir güzergāh-1 mehūf olmag̉la müstaḳil muhafaẓasına elli nefer tīrāndāzāne 'Abdullah bin Cübeyr rażiyellāhu 'anh ser'asker naṣb ve ol maḥalden vechen mine'l-vücūh 'adem-i infikākleri fermān buyurulub netice-i ve'l-kelām țarafeynden muharebeye şurū' birle avāze-i muḳātilīn meḳ ar-i feleki'l-eflāke resīde olūb evvel-i nehārda şāhid-i nuṣret sū-yi İslām'a cilve-numā oldig̀indan ġuzāt-1 müslimīn semt-i ġenāyime imāle-i licām-1 'azīmet ve me'mūr olān tīrāndāzāne mežkūr muhafaẓadan fāriğ kežālik aḩz-i māl dāìyesinde [4a] iken zūr-i bāzān cānib-i müşrikīn ol ma'ber-i mesdūdu's-sābıḳdan 'ubūr ̄̄dūb rāfi '-i livā-yı Rasūl-i kāināt 'aleyhi'ṣșalātu ve's-selām olan Muṣ'ab ibn 'Umeyr olub eṣnā-yı muhārebede 
352 | S. GÜR / Huzur Derslerine Katılan Kırım Uleması ve Muhammed Emin Efendi'nin Tefsir Metninin Neşri

Ṭalḥa bin 'Ușmān'ı ḳatl ve nīce iẓhār-1 şecā'at eyledikden sonra İbn Kamīye nām le 'īn-i bed-fercām fırșat bulub Muṣ 'ab'1 şehīd ve rindān-1 sa 'ādeti şehīd ve nīce aṣhāb-1 güzīn riżvānullāhi 'aleyhim ecme'īn zeḥm ālūd olub ve cānib-i müşrikīnden Muhammed ḳatl olundı deyu āvāze-i dehşet-i fezāyı hilāf-1 vāḳì zuhūr îtmekle berāy-1 hikmet-i rabbānī tertībāt-1 İslām halel-pezīr ve nīceler "men necā bi ra'sihi feḳad rabiḥa" hülyasıyla șuret-i firara nāẓır ve nīceleri cām-ı şehādet-i nūş ve mest ve medhūş olub bināberīn Rasūl-i hayru'l-beşere ve aṣhāb-1 kirām ve guzāt1 sābitūne tesliyetnāme-i rabbānī ve ru'b ve hirāslerini izāle ve ḳuvvet-i

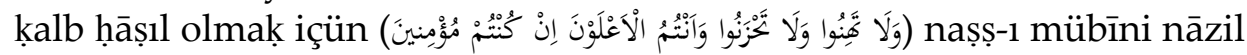
buyuruldı. Ya'ni ey mü'minīn sizlere iṣābet ìden cerh ve iżdırāb sebebiyle iẓhār-1 ża'f îtmeyin [4b] ve sizlerden maḳtūl ve şehīd olunanlara maḥzūn olmayın eger șaḥị̣an mü'min iseniz zīrā īmān Cenāb-1 vācibi'l-vücūda i timād ve i'tiḳād sebebiyle ḳuvvet-i ḳalb iḳtiżā ìder bir muhārebede șūret-i perīşāniyet rū-nümā olsa şer 'an tertỉbāt-1 umūr-1 ḥarbiyye ve levāzım-1 seferiyye hususuṣuna diḳkat-i tām ve sa 'yi mala kelām elzem olması lāzım gelūr. Șāhib-i Kebīr 'Allāme Rāzīis bu nükteye īmā īdūb beyān īder ki bu vaḳ adan muḳaddem küffār inhizām1 külli ile münhezim olup sū-i 'āḳıbetleri ve i'tiḳādı bāṭleleri mevcūd iken umūr-i harbde cidd ve ictihādlarına aṣlā fütūr virmeyüb def'a-i sāaniyede iḳdām eylediler me'a hāzāa ki ehl-i İslām olan zevāt-1 merḥūmeye fütūr ve ru'b ve hirās aṣlā lāyıḳ degildir intehā.

85 el-āyete. Bu āyet-i kerīme, āyet-i sābiḳanın tamamındandır. Ba 'żılar "ḳarḥ" lafł̣ını ḳāıın żammiyle ve ba'żllar fethiiyle kırāet īdūb kelimesinde ve ma'nā-yı lațîfinde kezāilik ihtilāf îdūb ba 'żlar fethile cerāḥa ve ba ż̇̇lar elem-i cerāḥa [5a] ma nāsına zahib oldılar. Ma 'nā-yı nașṣ-1 mübīn 'alā ḳavli'l-Ḳāżī "in eșabū minküm yevme uhudin feḳad eșabtüm minhüm yevme bedrin ${ }^{86}$ mișluh. ${ }^{87}$ Hulāṣa ma'nā eger sizlere yevm-i Uhud'da cerāḥa yāhūùd elem-i cerāḥa ve ıżdırāb ișābet eylediyse yevm-i Bedir'de taḥikiḳ-i misli onlara ya ni küffāra iṣābet eyledi dimekdir. Yāhūùd kilā'l-messeyn yevm-i Uḥud'da

\footnotetext{
84 Metinde Zârî.


الظَّالِمِينَ (Âl-i İmrân, 3/140)

86 Metinde "ر" harfi düşmüştür.

878
} 
S. GÜR / Crimean Ulama Who Participated in the Huzur Lessons and Publications of Quranic

Commentary Texts of Mohammed Emin Efendi| 353

vāḳi olmuşdur mā sebeḳde beyān olundīgī üzre. Zīrā evvel-i nehārda hezimet küffāra vāḳi olub ba dehu tīrāndāzān-1 mežkūr emr-i Rasūl 'aleyhi's-selāma muhalefetleri hasebiyle ba 'de'n-nehār şīrāze-i tertībāt-1 mü'minīn halel-pezīr olmuşdur. Bu taḳdirce āyet-i kerīmenin gazve-i Bedr'e delāleti mu'teber olmaz. 'Allāme Kāżì bu ma nāyı muaḩharen ḳ̂̄l unvanıyla 1̄sār eyledi. Zīrā "mișluh" lafz-1 şerīfi bu ma nāya zahiren māni'dir. Yevm-i Uhud'da muḳātele eḥedühümā āherīn mišli olmadiğına bināen. Zīrā kessret-i fevt ve mevt cānib-i İslām’da vuḳu bulub Hażreti Hamza ve nīce șahābī riżvānüllāhi 'aleyhim ecma īn efendilerimizin ke's-i şehādeti nūş buyurduḳları [5b] kütüb-i siyerde mesțurdur. Bu taḳdirce āyet-i kerīmede vāḳi lafz-i "ḳarh" mücerred inhizām ile tefsīr olunur. Bu ma nānın bu vecihle te'vile iḥtiyacından nāş̄ te'hīr ve bu üslūb ile edā ītmişdir.

Kelime-i tilke mübtedā ve evvel-i veḳāyi i 'acībeye işāret olmasını 'Allāme Rāzī beyān eyledi. Ammā ba'żı müfessirīn "kāffe-i ümem-i māżīye ve ātīye beyninde cārī olan eyyāma işāret olub ol yevm-i 'acībe dühūul-i evvelīn ile işārette dāhildir" deyü hükm eyledi. el-Eyyām lafẓ-1 şerīfi șıfat ve nüdāvilühā mübtedānın haberi yāhūd el-eyyām haber nüdāvilühā hāā olmaḳ muhtemeldir. 'Allāme Kāżī ve İbn-i Kemāl kāmil ve saair müfessirīn rahimehümüllāh "nașrifuhā beynehüm nüdīlü li hāulāi tāraten ve li hāulāi uhrā"88 ile tefsīr eylediler. Ya'ni ba'żan bir ḳavim içün ve ba'żan bir ḳavm-i āher içün eyyāmı galebe ḳılub beyne'n-nās ben 'aẓimu'ş-şān tașarruf 1̄derim. Ba'ż1 müfessirīn nașrın beynennās müşterek olmasını muḳteżā-i ma nāya mütecāsir oldılar cāiz degildir zīrā manṣıb-ı nuṣret e'azz ve a'ẓam mevādden olub küffāra [6a] lāyıḳ değildir ve hattā Peyġamber 'aleyhisselāma inhizām isnād olunsa müsnide tevbe tẹ̣līf olunup ḳabul ītmez ise ḳatli iḳtiżā eyledigini Kâàīi 'İyāż Şifā-i Şerîf' de beyān eyledi. Bināberīn ma'nā-yı āyet-i kerīme budur ki ba'żan miḥnet ve meşaḳkat küffār üzerine ve ba'żan İslām üzerine müşted olur ve bu āyet-i kerīmede nīce hịkmetler mevcuddur. Ezcümle eger cemi` vakitte miḥnet ve meşaḳkat küffār üzerine vāḳi olsa īmānın ḥaḳị̣ati ve sāir edyānın

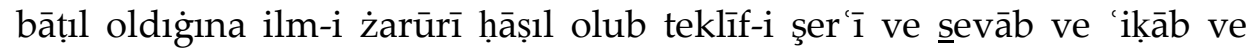
şehādet cümlesi bāṭle olur idi. Bu ecilden Hạ̣ sübhānehu ve te ālā miḥneti ba'żan İslām'a ve ba'żan küffāra teslịt buyurdı. Umūr-i

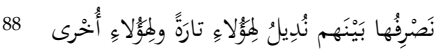


354 | S. GÜR / Huzur Derslerine Katılan Kırım Uleması ve Muhammed Emin Efendi'nin Tefsir Metninin Neşri

mežkūreler bāḳiye olması içün? ve mükellef olan zevāt-1 İslām'ın ḥaḳkiyyeti üzerine dāll-i delāile nażar vāṣıțasıyle i tiḳād-ı yakīnī hāạṣıl ider. Ammā İslām'a olan mị̣net ve meşaḳkat dünyada ba 'żı me'āṣīden nāşī te' dīb içün olub küffāra oldığı taḳdirce maḥża gażabullāh olaraḳdan zuhūr ìder deyu șahib-i Kebīr işaret eyledi.

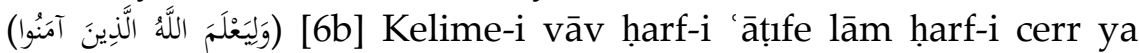
mukaddem ya muaḩher bir fi'le müte'alliḳdir. Taḳdīr-i kelām "veliya'lemellāhullez̄īne āmenū fe'alnā hāzihilmüdāvele" dīmeḳdir. Lākin ba '̇̇ müfessirīn bu āyet-i kerīmeyi bāb-ı temsīlden olmasını i'tibār îdūb ma'nen īmān üzerine sābit olmayanlardan īmān-ı kāmil üzerine sābit olan muhlișīni bilmek murād īden kimesnenin mu'āmelesi gibi mu'āmele olunmaḳ içün eyyāmı beyne'n-nās müdāvele ḳıldım ve bu āyet-i kerīme 'alā ḳavli'l-müfessirīn bir 'illet-i maḥzūfe üzerine ma țūfdur. 'İllet-i maḥzūfe beyān-1 Ḳāżì'ye göre "ey nüdāviluhā liyekūne keyte keyte" 89 böyledir ma'nāsı şöyle şöyle olmak içün dīmeḳdür ve 'umūm ifāde îden şey' taḳdīrinin sebebi mü'minīne meșāliḥden iṣābet îden eşya gayri ma lūm ve 'illeti dah̄i vāhịid olmasını īzān ve i'lāmdir. Yāhūùd 'ilimden murād ma lūmdur. Mütekellimūn bu āyete ve sāir nażīi āyetlerde țāife-i mu tezileleri red īdūb vācibü'lvücūd her bir eşyāi ve ḥudūṣu ḥavādiś-i ḳable'l-vuḳu bīlūr deyu iḥkāḳ-i hakḳ buyurdīler bu ecilden 'ilimden murād [7a] bu maḳāmda ma 'lūmdur. Mecāz-1 meşhūr olaraḳdan meselā "hāzāa 'ilmü fülān" dīrler. Murād, ma lūmu dīmeḳdir. Yohssa tạife-i mu tezile gibi zāhir-i āyet ile 'amel cāiz degildir. Bu ma 'lūm olduḳtan sonra Cenāb-1 vācibi'l-vücūd evvelā nifāḳdan iḩlāṣı temyīz ve mü'minīni kez̄ālik iạhār ve āşikār buyurdı ve 'ilmiñ lafẓatullāha ba 'de't-te'vīl iżāfeti tefhīm ve ta 'żīm iş'ār ider.

el āyete. Ya'ni sizlerden olan nāsı şehādet şerefiyle müşerref ve mükerrem eylemek içūn. Murād şühedā-i Uhuud'dur yāhūud lāfz-1 şühedā' şāhidiñ cem 'îdir. Bu taḳdirce ma nā mübālag̉a ile 'adālet edici oldukları ḥalde sizlerden şāhidler ittihāž itmek içūn dīmek olur. Sebeb-i 'adāletleri ḥaḳ üzerine sebāt ve miḥen ve şedāide taḥammülleridir. Zīrā yevm-i Uhud'da muhāfaẓa-i Rasūl-i Kāināt içūn nīce zevāt-ı ż̄ şān efendilerimiz fedā-yı cān ve maḳdurlarını șarf ìtmişlerdir. Tafṣ̣̂li kütüb-i siyerde mesțurdur. Bu zevāt-1 'ālī

898 
S. GÜR / Crimean Ulama Who Participated in the Huzur Lessons and Publications of Quranic

Commentary Texts of Mohammed Emin Efendi| 355

menziletlerini şanlarını tefhīm ve ta' ẓīm içün lāfẓ-1 ittihāž ile īrād buyuruld1.

[7b] (واللَُّ لا يُحِبُُ الظّالِمِينَ). Bu ḳavl-i şerîf bir cümle-i mu'teriża olub mā ḳablinin mażmūnunu taḳrīr içūn sevḳ buyuruldı. Lākin muhabbeti nefy bug்ż ve ġażabdan kināyedir ve zālimīne ị̂ā' 1 mukābilinde olan zevāt-1 'ādilīne muhabbeten zālimine tā'rìżdır. Murād ya īmān üzerine sābit olmayanlardır yāhūud kefere-i feceredir. Hāṣıll-ı ma 'nā Cenāb-1 vācibu'lvücūd zālimīne muhabbet ītmez. Ya'ni onlara bug்ż ve ġażab īder dīmeḳdir ve nașṣ-1 mübīn delālet īder ki küffāra haḳiḳaten nuṣret olmayub gālib olduḳları vaḳitte istidrācen yāhūd mü'minleri hikmeti maṣlaḥata bināen ibtilā içūndur. Zīrā nuṣret mahabbet iḳtiżā ìder zālimīne mahabbet yoḳdur. Bu taḳdirce nuṣret ehl-i īmāna mahṣuṣadır deyū 'Allāme Kāżì ve Ebussu'ūd rahimehumallāh beyān eylediler. Bu maḳama ḳadar żikr ve beyān āyet-i ātiyeniñ keşf ve īżāḥı içūndur.

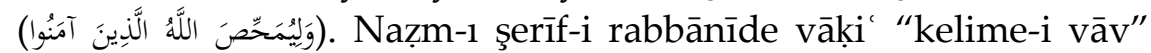
ḥarfi 'ātıfe ve "lām" ḥarf-i cerr "yumaḥḥıṣa" bāb-1 tef '̄ilden fi 'li mużāri ' en muḳaddere ile manșūb ve "yettehize minküm" ḳavl-i şerīfi üzerine [8a] ma'ṭūfdur. Ammā cānib-i ma'ṭūfun 'aleyhde lām i'āde buyurulmayūb cānib-i ma 'ṭūfda i'ādeniñ vechi şu vechile beyān olunur ki ve yettehize ḳavl-i şerīfi ifāde īder ki Cenāb-1 züulcelāliñ mü'minīnden şühedā ittiḩāžı ol kimesnelerin īmān-1 kāmil üzerine sebātlarını iş 'ār ìdüb mā ḳablinde vāḳı ' ve ma țūfun 'aleyh olan 'illet ile beraber güya 'illet-i vāhide menzilesinde olmag̉la bināen 'aleyh lām terk buyuruldı. Ammā "ve liyumeḥhisallāhullez̄ine" āyet-i kerīmesinde i'āde buyurulduġının vechi beyne'l-ma'țūf ve'l-ma'țūfu 'aleyh cümle-i mu'teriża ile faṣl olunub 'illiyyetini īzān ve iş‘ār içūndur ve cümle-i mu'teriżanıñ ba'dinde ityānıñ vechi mü'minīnin zümre-i zāalimīnde dühūl-i tevehhümini def'dir. Zīrā "ellez̄ine āmenū" ḳavl-i şerífiyle murād īmān üzerine sābīt olan zevāttır. Ammā 'Allāme Kāżì'nin "li yuṭahhirahum ve yuṣaffīhim mine' $\underline{z}$-züünubi in kāneti'd-dūletu 'aleyhim”' 90 ḳavliyle murād ya'ni Allāh züülcelāl evḳātı en-naṣru ve'l-galebetü beyne'l-müslimīn ve'l-kāfirīn müdāvele ḳılub eger galebe kāfirīn içūn hạạsıla olur ise murād temḥ̂sṣu'l-mü'minīn [8b] olur. Ya'ni onları züüūbden tațhīr ve tașfiye olur ve eger mü'minīn gālib olurlar ise

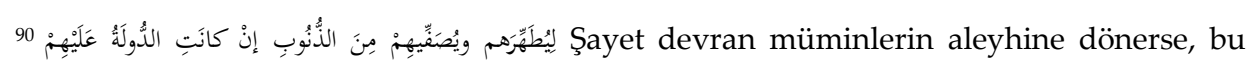
müminler için günahtan bir tasfiye ve temizlik dönemidir. 
356 | S. GÜR / Huzur Derslerine Katılan Kırım Uleması ve Muhammed Emin Efendi'nin Tefsir Metninin Neşri

murād, āsāar-1 kāfirīni mạ̣k ve maḥvdır. "İn kāneti'd-dūletu 'aleyhim" ḳavliniñ ma'nāsı eger kāfirīniñ mü'minīn üzerine galebesi olur ise dīmekdir. Zīrā "dūlet" galebe ma nāsınadır. Bu taḳdirce 'ilel-i selāse ya 'ni sābìt 'ale'l-īmān olanların gayr-i mü'minīnden temeyyüzi ve ittihāz̄-1 şühedā' ve temḥ̄ṣ cümlesi șāhịib-i Keşf'iñ ve Kāżì'nin zāhir kelāmlarına göre kāfirīniñ mü'minīn üzerine galebesine terettüb īden 'ileldir. Lākin hafī degildir ki 'ilelīn-i āhirīn mü'minīn kāfirīne gālib olduḳları vaḳıtta dah̄i ḥāṣıl olur ve züunūbdan temḥ̄ṣ kežālik mü'minīniñ kāfirīni muhāāebede ḳatl îtmesiyle ve 'aksiyle dahi ḥāṣıl olur.

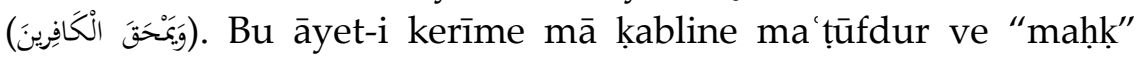
lügatta "noḳsān" ma nāsına ba 'żıların ḳavline göre "bir şey'i külliyyen ižhāb ve gidermek" ma nāsınadır. Ḥattā "ve yemḥekullāhurribā" kerimesi, "ey yeste'ṣlühü" ile tefsīr olundı. Ma nā-yı istīṣāl bir şeyi aṣl u bencinden ih̆rāc ìtmekdir.

[9a] Ammā bu ḳavl-i şerīf mü'minīn kāfirīn üzerine gaālib oldig̀i taḳdirce müdāvele-i mezkūrīn 'illetidir ve kāfirīnden murād yevm-i Uhudda Rasūl-i 'aleyhi's-selām ile muḥārebe īden müşrikīn ve āyet-i ūlādaki mü'minīnden murād muhārebe-i mezkūrede Rasūl-i 'aleyhi'sselāmın şeref-i mușạ̣̄abetlerinden aṣlā münfek olmayan zevāt-1 'ālīşāndır. 'Allāme Kāżììniñ "ve yuhlikehum in kānet 'aleyhim"92 ḳavliniñ ma'nāsı mü'minīn gālib olurlar ise kāfirīni ihlāk içündür dīmekdir. Ḩafī degildir ki bu naẓm-1 şerīf mașdarını̃ mef' ūlüne iżāfeti kabīlinden olub fā'iliniñ żikri terk buyuruldı. Taḳdīr-i kelām "ve yemḥaḳallāhu'l-kāfirīn" dīmekdir ve ba 'żan maḥ bir şeyin ḳalīlen ḳalīlen münteḳıṣ olmasına iṭlāḳ olunur. "Mehāḳu'l-ḳamer" bu ḳabildendir. Hulāṣa-i ma nā eger mü'minīn mag̀lūb olur ise züunūbden tațhīr ìtmek ve eger kāfirīn mag̀lūb olur ise āsāar-1 küfri maḥk ve maḥv ītmek içūndur dīmek olur. Rūhu'l-beyān șāhibi Haḳḳ ḳuddise sirruhu beyān īder ki, mü'minīni bu vecihle ibtilānın fāidesi isti dadlerinde [9b] olan kemālātı fi 'le ihrācdır. Meselā șabr ve şecā'at ve ḳuvvetü'l-yekīn ve nefse ḳıllet-i müblāt ve emrullāha teslīm ve bunuñ emsāli gibi ve her bir gam ve hemm ve meșāibi mü'minīne ișābet îttirirse züünūbini tekfīr ve ḳulūbini tațhīr ve ervaḥlarını taḩị̄̄ ve esrarlarını temḩ̄ṣ içūndūr. Ammā


2/276).

92 
S. GÜR / Crimean Ulama Who Participated in the Huzur Lessons and Publications of Quranic

Commentary Texts of Mohammed Emin Efendi| 357

kāfirīne iṣābet īden gerek ni met ve niḳmet ve gerek devlet ve zillet küfrāniyetlerine ve mezīd-i tuġyanlarına ve kalpleriniñ 'umyuna ve ervaḥlarını maḥka ve esrarlarını șahḳa sebebdir. Ve bu hușūṣa hadīs-i şerīf eşeddü'l-belāi 'ale'l-enbiyāi sümme'l-evliyāi sümme'l-emśeli fe'lemseli (أشدّ البلاء على الانبياء ثم الاولياء، ثم الامثل فالامثل) delīl-i ḳavī ve burhān-1 celīdir.

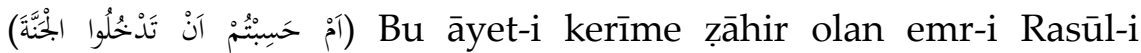
'aleyhi's-selāma muhālefet bir de yevm-i Uhudd'da perīşāniyyete sebeb olan kimesnelere hitabdır. Bu taḳdirce müdāvele-i eyyām-ı mūcibe olan esbāb tetimmesinden olmaḳ muhtemeldir. Zīra müdāvele-i mūcibe olan meşāḳḳa 'adem-i tahammül ve şedāid üzerine 'adem-i șabırdır. Yāhūôd emr-i Rasūl-i 'aleyhi's-selāma muhālefet īden kimesnelerin hāalini beyān içūn sevk olunmuş kelām-1 müste'nefe oldugì hāalde [10a] onları tebkīt ve tevbīh içün īrād buyurulmuş ola. Ve cemī' 'i nāṣ cennet-i a lāya meşaḳka taḥammül etmedikçe dāḩil olmayacaḳlarını beyāndır. Yāhūud müdāveleden gāyet ḳuṣvā olan meşīet beyānı içūn sevk buyurulmuş kelām-1 müste' nefe olması dah̄i cāizdir. Ammā 'Allāme Kāàż'nin "bel ehașibtüm" ḳavlinden garaż budur ki āyet-i kerīmede vāḳi' olan kelime-i "em" lafzen ve taḳdiren hemze-i istifhāmla gayr-i müsevveḳa olan kelāmıñ ibtidāsında vāḳi olan "em-i munḳațı 'a" olmasına işarettir. Zīrā merżā olan mežheb-i Zeccāc olub ānın "indinde "em" kelimesi hemze-i istifhām ile "bel" ma 'nāsını münżamindir. Ammā İmām Ferrā'ya göre "mīm" zāide olub faḳaṭ hemze-i istifhāmdan 'ibārettir ve bu maḳamda istifhāmdan murād inḳārī ve istib'ādī olub ma'nā sizler cennete duhūlünüzi zan mı ìdersiz zan ìtmeyin gàayet müsteb iddir zīrā sizden emr-i Rasūl-i 'aleyhi's-selāma muhālefet gibi 'adem-i dühūuli mūcib ḥarekāt-i nā pesendīde zuhūr eyledi. Bu taḳdirce inkār onların ḥusbānına ya ni z̧anlarına mütealliḳ olur. Yāhūd murād nehy-i hüsbāndır. [10b] Bu taḳdirce ma'nā-yı āyet-i kerime, dühūl-i cennete sebeb olan harekāt sizlerden șādır olmadıḳça dühūl-i cenneti z̧an îtmeyin dīmekdir. Lākin makṣūd olan tevbīh bu ma nāya göre müstefād olmaz.

Bir suāl teveccüh īder ki emr-i Rasūl-i 'aleyhi's-selāma muhālefet ìden kimesneler mü'minīn iseler cennete dühūlleri zannını inkār Allāh züu'l-celālin va'dine muhālifdir ve zanları mevḳı inde olur ve eger

93 "En şiddetli bela, peygamberlere, velilere ve benzerlerine gelir." 
358 | S. GÜR / Huzur Derslerine Katılan Kırım Uleması ve Muhammed Emin Efendi'nin Tefsir Metninin Neşri

münāfiḳin iseler dühūllerini inkār muvafıḳ olur. Lākin bu maḳamda vukū 'i siyāḳ-ı āyete muṭābık olmaz.

Cevāb, hüusbān-1 mežkūri inkār ile murād muhālefetlerini taḳbīhn ve șabr üzerine teşbīt ve taḥammül-i meşakḳa teşcī'dir. Yohșa zāāında zanlarını külliyyen inkār degildir.

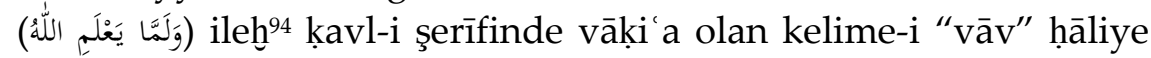
olub cümle-i mežkūre żamīr-i hasibtümden yāhūud żamīr-i tedhulūden hạal olub inkār mežkūri te'kīd içün ityān buyuruldı.

el-āyete. Vaṣf olan cihād nefy buyurulmayub 'adem-i cihād ile mevșūf olan kimesnelerden 'ilm nefy olunmasında hịkmet budur ki nefy-i cihadda mübālagia içūndūr. Zīrā Allāh züülcelāliñ [11a] biraz zevāttan 'ilmini nefy vașıfları olan cihaddan bi tarịki'lūlā nefyini muḳtezīdir. "Ve minküm” ḳavl-i şerīfi "ellez̄ine" ḳavl-i şerīfinden hāaldir. Ammā 'Allāme Ḳāżī'niñ "ve lemmā tücāhidū"95 ḳavlinden garaż budur ki "ve lemmā ya lemillāhüllez̄ine" ḳavl-i şerīfi "ve lemmā tücāhidū" maḳāminda olub nefy-i 'ilmden makṣūd ma lūm olan cihādı 'alā țarīkì'l-burhān nefiydir. Zīrā her bir ma 'lūmun taḥaḳkuki vücūdī Haḳk sübḥānehū ve te'ālā haż̇etlerinin ol ma'lūm ve mütehakḳiḳa 'ilmini müstelzim olub Ḩāliḳ te ālānıñ 'ilmi olmaḳsızın bir ma 'lūmun vücūdī müstehīl oldıgi bedāhete ma lūm oldıgina bināen her ma' lūm içūn elbette 'ilm-i rabbānī lāzımdır. Bu āyet-i kerīmede lāzım olan 'ilm "ve lemmā ya lemillāh" ileh ḳavl-i şerīfiyle nefy buyurıldıysa bedāheten melzūm olan cihādıñ nefy-i lāzım gelmekle ḳavl-i şerif-i mežkūr "ve lemmā tücāhidū" ile tefsīr olundı. 'Alā țarịki'l-burhān ma'nā-yı āyet-i kerīme şu vecihle rişte-i beyāna keşīde olunur ki mā meżāda [11b] sizlerden cihād vāki' olmadı eger vāḳi olaydı elbette Cenāb-1 āferīnendenin 'ilmi ta'allūḳ îder idi. Lākin 'ilm-i zü̈'l-celāl ta allūḳ îtmediyse cihad sizlerden șādır olmamak lāzım gelūr. Bu vecihle īrād her bir eşyaya Allāh te ālānın 'ilmi żarūrī olmasını iş ār īder. Ammā 'Allāme Ḳāżì'nin “ve'l-farḳu beyne lemmā ve lem enne fīhi tevaḳku 'e'lfi'li fīmā yüsteḳbel" beynini farḳdır. Zīrā ikisi de mużāri’a dāhil olub zeman-ı māżīde nefye delālet îderler. Vech-i farḳ budur ki lemmā kelimesi vaḳt-i intiẓārın

\footnotetext{
94 ilāāhnir.

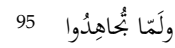

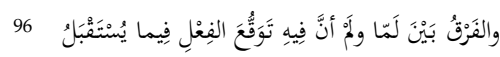


S. GÜR / Crimean Ulama Who Participated in the Huzur Lessons and Publications of Quranic

Commentary Texts of Mohammed Emin Efendi| 359

vaḳt-i tekellüme kadar cemī' 'i ezmine-i māżīnin cüzlerinde nefye delālet ider. Ba'de't-tekellüm menfi olan fi'lin husụuli müteveḳki' ve münteẓır olaraḳdan. Ammā lem kelimesi bunun hilāfına mulābese olub zemān-1 māżīnin ba'żı eczasında nefye delālet îder bilā teveḳku' kütüb-i naḥviyelerde tafṣili mežkūrdur. Huulāṣa-i kelām "ve lemmā ya 'lemillāhullezīne" ileh āyet-i kerīmesinde vāḳi olan lemmā kelimesi maḥātabīnden cemī' -i zemān-ı māżìde cihādın nefyine ve müstaḳbelde teveḳku una delālet īder [12a] ve ba 'żı müfessirīn mežkūre olan lemmā kelimesini lem ma'nāsına ḥaml eylediler.

Hulāṣaten ma'nā-yı āyet-i kerīme budur ki sizlerden zemān-1 māżīnin cemī' sinde yāhūùd ba 'żısında cihād vāḳi' olmadig̀ 1 halde büstān1 sermediye dühūlunuzi zan $\mathrm{m} ı$ ìdersiniz. Zannınız derece-i gāyedde müsteb ${ }^{1} \mathrm{i} d$ dir intehā.

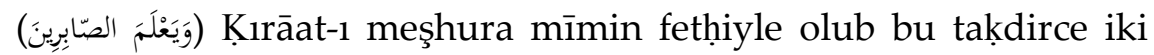
vecih vardır. Eşheri iżmār en ile manșub ve kelime-i vāv cemī' içūn olmaḳdır. "Lā te'küli's-semeke ve teşrabe'l-lebene" ${ }^{97}$ ḳavli gibi "ve en teşrabe'l-lebene" 98 taḳdīrindedir. Ya'ni ikisinin beynini cem 'ìtmeyen 'ulemā-i Baṣra bu veche zāāhib oldılar. Ammā Kūfiyyūn bu meḳūle vāva vāv-1 șarf ta 'bir īderler. Ya'ni teşrab fi'li mā ḳablinde vāki' olan fi 'lin i'rābı gibi i rāb olunmaḳ lāzım iken vāvın duhūli i'rabdan vech-i āḩere șarf eyleyūb āhiri meftūḥ old1. Ammā vech-i gayr-i meşhūr budur ki 'an aṣl ya 'lem fi 'li meczūm olub vaktāki ba 'dinde sākin vāḳi oldıysa iltikāāi sākineyn ref' olmaḳ içün ehaff-i ḥarekāttan olan fetḥa iḩtiyār [12b] olunmag̉la āhiri meftūḥ oldı. Lākin 'Allāme'niñ "ve ḳurie bi'r-raf'i ileh" kavlinden garaż budur ki 'Amr bin el-'Alā'dan rāvī olarak 'Abdülvāris ve ya 'leme laf̧̣-1 şerīfini merfū' an ḳırāat ītmişdir. Bu taḳdirce kelime-i vāv hạāliye olur. Eger fi 'l-i mużāri' müşbet üzerine vāv-1 hạaliyeniñ duhūli cāiz degildir deyu i tirāż teveccüh īder ise cevāb budur ki bu makāanda mużāri mübtedā-yı maḥzūfuñ haberidir. Taḳdīr-i kelām "ve hüve ya 'lemu'ṣ-șābirīn" olub bu șurette ma 'nā-yı āyet-i kerīme böyle olur ki sizler şedāyide mütaḥammil olmadig̀ınız halde ve cemī'-i zemānı māżīde yāhūd ba żì zemān-ı māżīde sizlerden cihād fī sebīlillāh vāki olmadig̀ı halde cennet-i a lāya dühūlunuzi zannınız derece-i gāyette

97 لا تَأْكُلِ السَمَكَ وتَشْرَبَ اللَبَنَّ Hem balık yiyip hem de süt içme.

98 
360 | S. GÜR / Huzur Derslerine Katılan Kırım Uleması ve Muhammed Emin Efendi'nin Tefsir Metninin Neşri

müsteb 'îddir. Z̄irā dühūl-i cennet ve terk-i mușābere 'ale'l-cihād cem ' olmazlar.

Hulāṣa-i kelām huubb-i dünyā sa'ādet-i uhrā ile müctemi' olmaz. Eheduhumā müzād oldukç̧a āher nāḳıș olur. Zīrā sa ādet-i dünyā ancak ḳalbin umūr-i dünyāya iştiḡāliyle hạạ̦ıl olur [13a] ve sa ādet-i uhrā ancaḳ mā sivallāhdan fārigigill-bāl olmag̉la olur emrānın ictimā'i mümḳin olmamag̉la bu șırr içün āyet-i kerīmede istib'ād-1 şedīd vāḳi olub mā sebeḳde vāḳi tesliyetnāme-i "ve lā tehinū" dan iżrāb ve emr-i Rasūl 'aleyhi'ṣ-ṣalāt ve's-selāma muhālefet îden kimesnelere bu vecihle tebkīt ve tevbīh olaraḳdan bu āyet-i kerīme vārid buyurulmuşdur. "Ve șābirīn" sīgāà ism-i fā il olmag̉la mu teber olan șabr üzerine istimrār ve devām şart oldıġını iş ‘ār īder.

Hāzaā āhiru mā teyessera lenā fī hāże'l-meḳām min tahrīiri'l-merām in vaḳa 'a fīhi sehven ev hațaen fercu'l-'afve minellāhi'l-'allām innehū hüve'l-'afuvvu'l-gafūr.

\section{Kaynakça}

Albayrak, Sadık. Son Devir Osmanlı Uleması. 5 Cilt. İstanbul: Milli Gazete Yayınları, 1980.

Alpaydın, Mehmet Akif. "Hulâsatü'l-Mukarrirîn: Huzur Dersi'nde

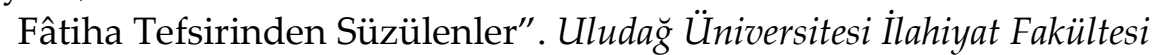
Dergisi 27/1 (2018), 193-210.

Arpa, Recep. "Huzur Derslerinde Kâdî Beydâvî Tefsiri mi Takip Edilirdi?". Osmanlıda Tefsir Dersi Gelenekleri. ed. Ömer Kara vd.. 91156. İstanbul: İlim Yayma Vakfı Kur'ân ve Tefsir Akademisi Araştırmaları, 2018.

Atâ, Tayyarzâde. Osmanlı Saray Tarihi/Tarih-i Enderun. 5 Cilt. nşr. Mehmet Arslan. İstanbul: Kitabevi, 2010.

Bursalı, Mehmed Tahir. İdâre-i Osmâniye Zamanında Yetişen Kırım Müellifleri. İstanbul: Matbaa-i Orhaniye, 1335.

Demirpolat, Enver. "Huzur Derslerine Katılan Harputlu Âlimler". Firat Üniversitesi İlahiyat Fakültesi Dergisi 17/2 (2012), 213-237.

İnalcık, Halil. "Kırım". Türkiye Diyanet Vakfi İslâm Ansiklopedisi. 25/450458. Ankara: TDV Yayınları, 2002.

İpşirli, Mehmet. "Huzur Dersleri”. Türkiye Diyanet Vakfi İslâm Ansiklopedisi. 18/441-444. Ankara: TDV Yayınları, 1989. 
S. GÜR / Crimean Ulama Who Participated in the Huzur Lessons and Publications of Quranic Commentary Texts of Mohammed Emin Efendi| 361

İlmiyye Salnamesi (Osmanlı İlmiyye Teşkilatı ve Şeyhülislamlar). haz. Seyit Ali Kahraman vd.. İstanbul: İşaret Yayınları, 1998.

Kara, Ömer. "İslâm Geleneğinde Ümerâ Huzurundaki Bilimsel Toplantıların Osmanlicasi: Huzur Dersleri". Osmanlı Toplumunda Kur'an Kültürü ve Tefsir Çalışmaları 2/299-369. İstanbul: İlim Yayma Vakfı Kur'ân ve Tefsir Akademisi, 2013.

Kara, Ömer. "Osmanlı'da Huzur Dersleri Geleneği Literatürü". Türkiye Araştırmaları Literatür Dergisi 9/18 (2011), 519-539.

Kartal, Alparslan. "Huzur Derslerine Katılan Karslı Âlimler". Kafkas Üniversitesi Illahiyat Fakültesi Dergisi 4/8 (2017), 224-243.

Kavak, Nuri. Osmanlı Bürokrasisinde Görev Almış Kırım Kökenli Devlet Adamları. İstanbul: Has Matbaacilik, 2017.

Kırımlı Muhammed Emin b. Esad Efendi. Âl-i İmrân Sûresi 139-142 Âyetlerin Tefsiri. İstanbul: İstanbul Üniversitesi Kütüphanesi (Yıldız Sarayı Kütüphanesi Eserleri), Türkçe Yazmalar Bölümü, 7297, 1b-13a.

Mardin, Ebül'ulâ. Huzur Dersleri. 3 Cilt. İstanbul: İsmail Akgün Matbaası, 1951 (2 ve 3. Ciltler 1966' da aynı matbaada basılmıştır).

Pakalın, Mehmet Zeki. Osmanlı Tarih Deyimleri ve Terimleri Sözlüğü. 3 Cilt. İstanbul: Milli Eğitim Bakanlığı Yayınları, 4. Basım, 1993.

Süreyyâ, Mehmed. Sicill-i Osmânî Yahud Tezkire-i Meşâhir-i Osmaniyye (I-

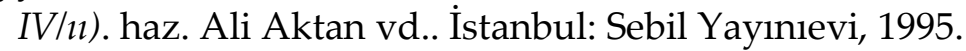

Temizer, Aydın. “Osmanlıda Huzur Dersi Örnekleri Tahlil ve Tenkitli Tefsir Metni Neşirleri I". Sakarya Üniversitesi İlahiyat Fakültesi Dergisi 15/28 (2013), 65-92.

Uşaklıgil, Halit Ziya. Saray ve Ötesi: Son Hatıralar. İstanbul: Özgür Yayınları, 2003.

Uzunçarşılı, İsmail Hakkı. Osmanlı Devleti'nin İlmiye Teşkilatı. Ankara: Türk Tarih Kurumu Yayını, 1965.

Yüksel, Ahmet - Karademir, Zafer. “Ulema, Göç ve Devlet: Kırım Harbinden Sonra Osmanlı Ülkesine Göç Eden Ulemanın İskânına Dair Bazı Bilgiler". Ankara Üniversitesi Dil ve Tarih-Coğrafya Fakültesi Dergisi 52/1 (2012), 169-190. 